\title{
Nutritive and photosynthetic ecology of subsurface chlorophyll maxima in Canadian Arctic waters
}

\author{
J. Martin ${ }^{1}$, J. É. Tremblay ${ }^{1}$, and N. M. Price ${ }^{2}$ \\ ${ }^{1}$ Québec-Océan \& Département de Biologie, Université Laval, Québec, QC, G1V 0A6, Canada \\ ${ }^{2}$ Department of Biology, McGill University, Montréal, Québec, QC, H3A 1B1, Canada
}

Correspondence to: J. Martin (johannie.martin.1@ulaval.ca)

Received: 4 May 2012 - Published in Biogeosciences Discuss.: 6 June 2012

Revised: 12 November 2012 - Accepted: 27 November 2012 - Published: 21 December 2012

\begin{abstract}
Assessments of carbon and nitrogen (N) assimilation in Canadian Arctic waters confirmed the large contribution of subsurface chlorophyll maxima (SCM) to total water-column production from spring to late fall. Although SCM communities showed acclimation to low irradiance and greater nitrate $\left(\mathrm{NO}_{3}^{-}\right)$availability, their productivity was generally constrained by light and temperature. During springearly summer, most of the primary production at the SCM was sustained by $\mathrm{NO}_{3}^{-}$, with an average $f$-ratio (i.e., relative contribution of $\mathrm{NO}_{3}^{-}$uptake to total $\mathrm{N}$ uptake) of $0.74 \pm 0.26$. The seasonal decrease in $\mathrm{NO}_{3}^{-}$availability and irradiance, coupled to the build up of ammonium $\left(\mathrm{NH}_{4}^{+}\right)$, favoured a transition toward a predominantly regenerative system $(f$ ratio $=0.37 \pm 0.20$ ) during late summer and fall. Results emphasize the need to adequately consider SCM when estimating primary production and to revisit ecosystem model parameters in highly stratified Arctic waters.
\end{abstract}

\section{Introduction}

In the Arctic Ocean, the extreme solar cycle and the formation, ablation and motion of sea ice exert a major influence on light availability in the water column (Smith and Harrison, 1991; Sakshaug, 2004). While these processes constrain the timing of algal production and impose large, short-term light fluctuations during the growth period, first-order differences in the annual primary production of seasonally open waters ultimately depend on mixing regime, which modulates the supply of nitrogen $(\mathrm{N})$ to the upper euphotic zone (Tremblay and Gagnon, 2009; Ardyna et al., 2011).
In peripheral Arctic seas (e.g., Bering Sea, Barents Sea, eastern Baffin Bay), the relatively weak vertical stratification allows for vertical mixing that recharges the euphotic zone with nutrients at least once a year (Tremblay et al., 2002). In the interior (e.g., Chuckchi and Beaufort seas), however, low-salinity waters entering through Bering Strait and the freshwater supplied by rivers impart strong vertical stratification. Although large quantities of nutrients are supplied by the Bering Sea, $\mathrm{N}$ is depleted in the surface waters of the Chukchi Sea and weakly replenished downstream in the Beaufort Sea (Tremblay et al., 2008). In the coastal Canadian Arctic, the pycnocline is shallow nearly everywhere (between 14 and $32 \mathrm{~m}$ ) but is stronger in the west (where the Brunt-Väisälä, or buoyancy frequency $-N^{2}$, reaches up to $0.004 \mathrm{~s}^{-2}$ in Amundsen Gulf) than in the east (where $N^{2}$ generally ranges from 0.0006 to $0.002 \mathrm{~s}^{-2}$ in Baffin Bay and Lancaster Sound; Martin et al., 2010).

Recent work showed that strongly opposing vertical gradients of irradiance and inorganic $\mathrm{N}$ in the coastal Canadian Arctic result in the widespread occurrence of subsurface chlorophyll maxima (SCM). These SCM are located relatively high in the euphotic zone and show a strong association with the nitracline by comparison with those observed in other oceans (e.g., SCM in tropical oceans are located at the base of or below the euphotic zone, above the nitracline and do not correspond to a biomass or productivity maximum; Martin et al., 2010). Arctic SCM communities are numerically dominated by flagellates with important contributions of large-sized diatoms (Ardyna et al., 2011; Palmer et al., 2011; Martin et al., 2010) that presumably account for a disproportionate share of the carbon biomass and productivity. 
Since the Canadian Arctic represents a large portion of the Arctic (ca. 27\%) and because SCM are seasonally persistent, highly photosynthetically competent and closely associated with the nitracline, Martin et al. (2010) hypothesized that SCM mediate a large share of new production, i.e., the portion of total primary production based on the uptake of allochthonous $\mathrm{N}$ (e.g., nitrate, $\mathrm{NO}_{3}^{-}$). Due to their positioning in the water column, SCM probably act as a "nutrient trap" that further weakens $\mathrm{N}$ renewal and new production in the upper euphotic zone (see also Taylor et al., 1986 and Harrison, 1990). However, Martin et al. (2010) also found that most SCM in the Canadian Arctic operate at very cold temperatures $\left(<1^{\circ} \mathrm{C}\right)$, which possibly limits their contribution to water-column productivity since phytoplankton do not exhibit specific adaptations to low temperature in the Arctic (Platt et al., 1982; Smith and Harrison, 1991).

In the study of Martin et al. (2010), the combination of low levels of ammonium $\left(\mathrm{NH}_{4}^{+}\right)$at and above the $\mathrm{SCM}$ with rapidly increasing concentrations underneath suggested that local $\mathrm{N}$ recycling is important for SCM communities. It follows that regenerated production possibly fuels a substantial part of total primary production on a daily basis. When abundant, reduced $\mathrm{N}$ (i.e., $\mathrm{NH}_{4}^{+}$and urea) is generally preferred over $\mathrm{NO}_{3}^{-}$, whereas all $\mathrm{N}$ forms tend to be used in proportion to their availability when total $\mathrm{N}$ is lower than phytoplankton demand (McCarthy et al., 1977; Harrison et al., 1982). Whether SCM communities are predominantly regenerative or efficient vectors of export toward top predators or the deep ocean remains to be assessed.

The main objective of this study was to evaluate the uptake of carbon (C) and $\mathrm{N}$ by primary producers respond to the availability of light and nutrients at the SCM. Secondary goals were to generate uptake-irradiance parameters to inform ecosystem models or remote-sensing algorithms, and to produce a preliminary assessment of the relative contribution of SCM layers to water-column production, based on a limited comparison of surface and SCM samples. In selecting a methodological approach, we also considered previous studies showing that $\mathrm{C}$ and $\mathrm{N}$ uptake can be partly decoupled in the short term (i.e,. may not lead to primary organic synthesis), especially at low irradiances such as observed at the SCM (Price et al., 1985; Cochlan et al., 1991; Smith and Harrison, 1991). This decoupling can be caused by luxury uptake, whereby algae store $\mathrm{NO}_{3}^{-}$or release $\mathrm{NO}_{2}^{-}$after incomplete reduction, bacterial $\mathrm{N}$ uptake (Kirchman and Wheeler, 1998; Allen et al., 2002), or a greater capacity for algal $\mathrm{N}$ uptake (relative to C) under low irradiance (Smith and Harrison, 1991; Probyn et al., 1996). For all these reasons, we elected to measure $\mathrm{C}$ and $\mathrm{N}$ uptake simultaneously, using short-term incubations in light-gradient, laboratory modules, instead of classical 24-h incubations on deck (e.g., Simpson et al., 2012; Brugel et al., 2009; Fouilland et al., 2007; Smith et Harrison, 1991; Harrison et al., 1982; Platt et al., 1982). The latter are useful to provide daily rates and biogeochemical snapshots

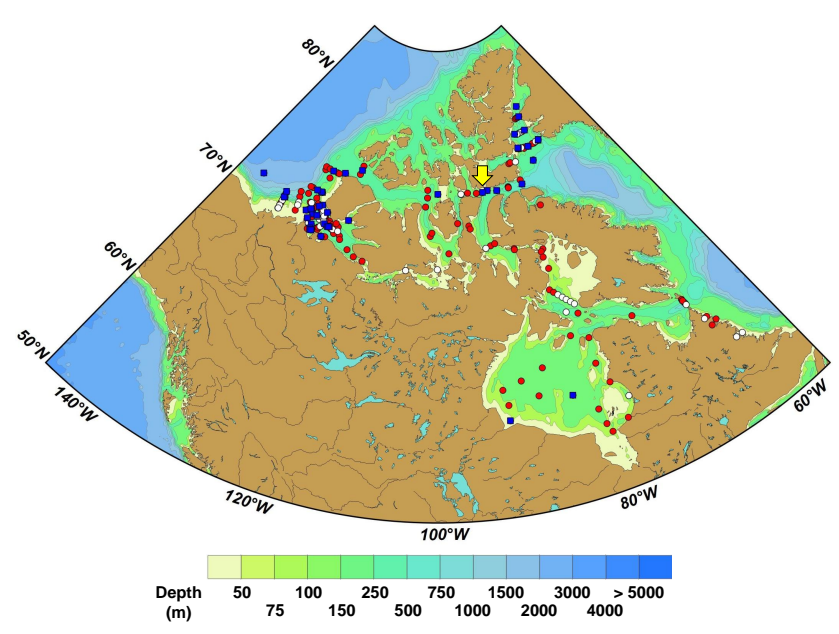

Fig. 1. Locations of all sampling stations (red circles) and those where incubations were performed (blue squares). Open symbols represent stations with no visible SCM, and the yellow arrow points to station 303 , which is analyzed separately in the text.

at a given location, but do not provide dynamical parameters (e.g., maximum uptake at light saturation, initial slope of the uptake-irradiance relationship) to quantify and model physiological state, acclimation, and responses to experimental or natural changes in growth conditions.

\section{Materials and methods}

\subsection{Sampling}

During 2005 (16 August to 16 October), 2006 (4 September to 4 November), 2007 (28 September to 6 November) and 2008 (26 April to 13 July) expeditions of the CCGS Amundsen, 983 vertical profiles were obtained with a CTD-rosette equipped with sensors to measure in vivo fluorescence (Seapoint Chlorophyll Fluorometer), transmissivity (WET Labs CST-671DR), dissolved oxygen (SeaBird SBE43), $\mathrm{NO}_{3}^{-}$(Satlantic ISUS V1), photosynthetically active radiation (PAR; Biospherical QCP-2300), temperature and salinity (Sea-Bird SBE-911plus). Our sampling covered the entire latitudinal and longitudinal swath of the Canadian Archipelago, including Baffin Bay, the Northwest Passage, the Beaufort Sea, Foxe Basin, Hudson Bay and three Labrador fjords (Fig. 1).

\subsection{Nutrients}

Nutrient determinations were performed at subsets of 265 stations for $\mathrm{NO}_{3}^{-}$and $\mathrm{NO}_{2}^{-}$(55 in 2005, 85 in 2006, 52 in 2007 and 73 in 2008) and 129 stations for $\mathrm{NH}_{4}^{+}$(35 in 2005, 29 in 2006, 22 in 2007 and 43 in 2008). Samples were taken at the SCM and at standard depths $(5,10,20,30,40,50,60$, $70,80,100,125,150,175,200,250,300 \mathrm{~m}$ and then every $100 \mathrm{~m}$ where the Arctic halocline was not present. Otherwise, 
sampling in the 100-200 $\mathrm{m}$ range occurred at every $20 \mathrm{~m}$ and at a salinity of 33.1 to capture the nutrient maximum; see Martin et al., 2010 for details). Samples were collected in acid-cleaned tubes (stored with $10 \% \mathrm{HCl}$ ) and stored in the dark at $4{ }^{\circ} \mathrm{C}$. Concentrations of $\mathrm{NO}_{3}^{-}+\mathrm{NO}_{2}^{-}$and $\mathrm{NO}_{2}^{-}$were determined within a few hours using standard colorimetric methods (Grasshoff et al., 1999) adapted for the AutoAnalyzer 3 (Bran + Luebbe), and $\mathrm{NH}_{4}^{+}$was measured manually with the sensitive fluorometric method (Holmes et al., 1999). For the latter, reagents were added within minutes of sample collection. Urea samples were either frozen or analyzed fresh using the method of Mulveena and Savidge (1992) and Goeyens et al. (1998). The analytical detection limits for $\mathrm{NH}_{4}^{+}$and urea were $0.02 \mu \mathrm{M}$ and $0.1 \mu \mathrm{M}$, respectively.

\subsection{Chlorophyll and $F_{v} / F_{m}$}

Chlorophyll $a(\operatorname{chl} a)$ concentration and photosynthetic competency $\left(F_{v} / F_{m}\right)$ at the surface $(5 \mathrm{~m})$ and the SCM depth were analysed at the 129 stations where $\mathrm{NH}_{4}^{+}$determinations were also performed (see Sect. 2.2). Concentrations of chl $a$ were determined using the fluorescence method (Parsons et al., 1984) and $F_{v} / F_{m}$ by pulse-amplitude modulated fluorometry (WALZ PHYTO-PAM; see details in Martin et al., 2010). $F_{v} / F_{m}$ measurements were also used to assess the response of SCM and surface communities to experimental treatments. Samples were obtained from bottles after their incubation and dark adapted for $30 \mathrm{~min}$ before analysis.

\subsection{Incubations}

Of the 129 stations sampled for chl $a$ concentrations and $F_{v} / F_{m}, 59$ were selected for light-gradient incubations with water collected at SCM depth (11 in 2005, 12 in 2006, 10 in 2007 and 26 in 2008). In 2006, 9 of the 12 incubations examined $\mathrm{NO}_{3}^{-}$uptake simultaneously for surface $(5 \mathrm{~m})$ and SCM communities (Table 1). Most samples were taken during the local morning. Relationships between PAR ( $E$; estimated with a Biospherical QSL-2101 light sensor) and the uptake of $\mathrm{C}$ and $\mathrm{N}$ by phytoplankton from the SCM were assessed in four, ten-position light-gradient incubators designed to minimize spectral shift and accurately resolve photosynthetic parameters, especially in oligotrophic waters (Babin et al., 1994). Full-spectrum, 400-W Optimarc metal-halide lamps mimicking solar irradiance were used in combination with a blue filter (118 Light Blue Lee Filters Ltd.) and optically neutral filters (Lee Filters) to simulate the coastal underwater light spectrum (Hill and Cota, 2005; Carmack et al., 2004; Harrison et al., 1977). Actual PAR values in the incubators were kept in the low range to reproduce conditions near the SCM (from 664.2 to $0.3 \mu \mathrm{mol}$ quanta ${ }^{-1} \mathrm{~m}^{-2} \mathrm{~s}^{-1}$ in 2005 , with 6 of the 10 light intensities below $100 \mu$ mol quanta $\mathrm{m}^{-2} \mathrm{~s}^{-1}$ and from 309.1 to $1.8 \mu$ mol quanta $^{-1} \mathrm{~m}^{-2} \mathrm{~s}^{-1}$ in 2006, 358.0 to $3.0 \mu$ mol quanta ${ }^{-1} \mathrm{~m}^{-2} \mathrm{~s}^{-1}$ in 2007 and 281.0 to
$1.8 \mu$ mol quanta ${ }^{-1} \mathrm{~m}^{-2} \mathrm{~s}^{-1}$ in 2008 , with 8 or 9 of the 10 light intensities below $100 \mu$ mol quanta $\mathrm{m}^{-2} \mathrm{~s}^{-1}$ ). Temperature was maintained at in situ levels with a chilling circulator.

Samples from all incubators were spiked with ${ }^{13} \mathrm{C}$ bicarbonate; one incubator was enriched with ${ }^{15} \mathrm{NO}_{3}^{-}$ $(10 \mu \mathrm{M})$ and another with either ${ }^{15} \mathrm{NH}_{4}^{+}(4 \mu \mathrm{M})$ or ${ }^{15} \mathrm{NO}_{2}^{-}$ $(2 \mu \mathrm{M})$. The other two incubators received trace additions (10\% of ambient concentrations) of the same $\mathrm{N}$ substrates. Experiments that compared surface and SCM communities were performed with enriched and trace additions of ${ }^{15} \mathrm{NO}_{3}^{-}$only. Incubations were kept short $(5-6 \mathrm{~h})$ to minimize isotopic dilution and were terminated by filtration onto 24-mm glass microfiber filters (Whatman GF/F; vacuum pressure $<250 \mathrm{~mm} \mathrm{Hg}$ ). All filters were desiccated at $60^{\circ} \mathrm{C}$ and stored dry for post-cruise analysis. An elemental analyzer (ECS 4010, Costech Analytical Technologies Inc.) coupled to a mass spectrometer (Delta V Advantage, ThermoFinnigan) was used to determine isotopic enrichment and particulate organic carbon and nitrogen using a modified Dumas method (for details see Blais et al., 2012). Specific C and N uptake were calculated using Eq. (3) of Collos (1987).

\subsection{Data transformations and calculations}

Detailed vertical profiles were obtained with a CTD (conductivity, temperature, depth) and attached sensors (see Martin et al., 2010 for detailed post-calibration procedures). The depths $(Z)$ of the pycnocline and nitracline were identified as those where the vertical gradients of the Brunt-Väisälä (or buoyancy) frequency $\left(N^{2} ; \mathrm{s}^{-2}\right)$ and $\mathrm{NO}_{3}^{-}$had the highest values, respectively. The depth of the SCM was defined as the depth where the in vivo fluorescence was at a maximum. Daily averaged PAR at the SCM $\left(E_{\mathrm{SCM}}\right)$ and at other sampling depths was calculated using the coefficient of diffuse light attenuation ( $k$; see Martin et al., 2010 for calculation method) and a continuous record of incident PAR above the sea surface (Kipp \& Zonen; PAR Lite) to estimate $E_{0}$. Values of $E_{0}$ were corrected for surface reflectance based on the work of Sakshaug and Slagstad (1991) and assuming a mean loss of $7.5 \%$ for the high Canadian Arctic (Mei et al., 2002).

Chl $a$ normalized (superscript $B$ ) photosynthesisirradiance parameters (and standard errors on these parameters) were calculated using the empirical exponential models that provided the best fit to the data. The model of Platt et al. (1980) was used when photoinhibition occurred:

$$
P^{B}=P_{s}^{B}\left[1-\exp \left(-\alpha E / P_{s}^{B}\right)\right]\left[\exp \left(-\beta E / P_{s}^{B}\right)\right]
$$

with

$$
P_{m}^{B}=P_{s}^{B}[\alpha /(\alpha+\beta)][\beta /(\alpha+\beta)]^{\beta / \alpha},
$$

and the model of Webb et al. (1974) was used when photoinhibition was not apparent:

$$
P^{B}=P_{m}^{B}\left[1-\exp \left(-\alpha E / P_{m}^{B}\right)\right]
$$


where $P_{m}^{B}$ is the maximum observed uptake rate $[\mu \mathrm{g} \mathrm{C}$ $(\mu \mathrm{gchl} a)^{-1} \mathrm{~h}^{-1}$ ], $E$ is the incubation irradiance (PAR, $\mu$ mol quanta $\mathrm{m}^{-2} \mathrm{~s}^{-1}$ ), and $\alpha$ and $\beta$ in units of $[\mu \mathrm{gC}$ $(\mu \mathrm{g} \text { chl } a)^{-1} \mathrm{~h}^{-1}\left(\mu \mathrm{mol} \text { quanta } \mathrm{m}^{-2} \mathrm{~s}^{-1}\right)^{-1}$ ] are the photosynthetic efficiency at low irradiance (initial slope of the relationship) and the photoinhibition parameter, respectively. The models of Platt et al. (1980) and Webb et al. (1974) were previously shown to give similar results (Frenette et al., 1993). The photoacclimation index $\left(E_{k}\right.$; $\mu$ mol quanta $\mathrm{m}^{-2} \mathrm{~s}^{-1}$ ) was calculated as

$E_{k}=P_{m}^{B} / \alpha$.

The same model parameters were estimated for nitrogen uptake (in which case the letter $N$ substitutes for $P$ in Eqs. (1) to (3) and $\mathrm{N}$ form identified with subscript $\mathrm{NO}_{3}, \mathrm{NO}_{2}$ and $\left.\mathrm{NH}_{4}\right)$, with the inclusion of a term for dark uptake $\left(D^{B}\right.$ in [ $\mu \mathrm{g} \mathrm{N}(\mu \mathrm{g} \mathrm{chl} a)^{-1} \mathrm{~h}^{-1}$ ] on the right-hand side of Eqs. (1) and (3) (Priscu, 1989)). While some studies also include a dark term for $\mathrm{C}$ uptake, here the intercept of the initial slope of the photosynthesis-irradiance relationship never differed significantly from zero. A more robust estimation of $D^{B}$ for $\mathrm{N}$ uptake was done a posteriori by taking the y-intercept $(E=0)$ of the linear portion of the relationship at low irradiance. On average, standard errors were $8 \pm 7 \%, 11 \pm 8 \%$ and $15 \pm 9 \%$ for the photosynthetic parameters $P_{m}^{B}, \alpha$ and $E_{k}$, respectively, and $21 \pm 36 \%, 31 \pm 27 \%, 54 \pm 70 \%$ and $41 \pm 44 \%$ for the $\mathrm{N}$ uptake parameters $N_{m}^{B}\left(\mathrm{NO}_{3}\right.$ and $\left.\mathrm{NH}_{4}\right)$, $\alpha_{\left(\mathrm{NO}_{3} \text { and } \mathrm{NH}_{4}\right)}, D_{\left(\mathrm{NO}_{3} \text { and } \mathrm{NH}_{4}\right)}^{B}$ and $E_{k}\left(\mathrm{NO}_{3}\right.$ and $\left.\mathrm{NH}_{4}\right)$, respectively. For consistency with all other Arctic studies reporting uptake-irradiance parameters obtained with artificial light sources (Gallegos et al., 1983; Lewis and Smith, 1983; Gosselin et al., 1986; Harrison and Platt, 1986; Hirche et al., 1991; Kristiansen and Lund, 1989; Kristiansen and Farbrot, 1991; Kristiansen et al., 1994; Cota et al., 1996; Carmack et al., 2004; Palmer et al., 2011) and due to our need to compare photosynthesis and $\mathrm{N}$ uptake (whose coupling with photochemistry is not as straightforward as for $\mathrm{C}$ fixation), we did not perform a posteriori corrections of $\alpha$ for differences in light spectrum between the incubators and the water column.

Since irradiance varied between incubators, the $f$-ratio $\left(N_{\mathrm{NO}_{3}}^{B} / N_{\mathrm{NO}_{3}}^{B}+N_{\mathrm{NH}_{4}}^{B}\right)$ at a given irradiance was calculated using uptake values predicted from individual $N^{B}-E$ curves for $\mathrm{NO}_{3}^{-}$and $\mathrm{NH}_{4}^{+}$. The resulting $f$-ratio- $E$ curves were used to assess the $f$-ratio and the relative preference index (RPI) for $\mathrm{NO}_{3}^{-}$uptake at $E_{S C M}$. The RPI was calculated by dividing the $f$-ratio by the relative contribution of $\mathrm{NO}_{3}^{-}$to total inorganic $\mathrm{N}$ concentration $\left(\mathrm{NO}_{3}^{-}+\mathrm{NH}_{4}^{+}\right)$and represented the degree to which $\mathrm{NO}_{3}^{-}$was selected (RPI $>1$ ) or discriminated (RPI < 1) over $\mathrm{NH}_{4}^{+}$(McCarthy et al., 1977).

\subsection{Statistical analyses}

The geometric mean regression (model II linear regression; considering error on both variables) was used to assess functional relationships between variables. Relationships between environmental variables and uptake-irradiance parameters for $\mathrm{C}$ and $\mathrm{N}$ were determined with the Pearson's product moment correlation (PPMC), and differences between treatments were evaluated with a paired t-test when data were distributed normally or the Wilcoxon signed-rank test otherwise (SigmaPlot 11, Systat Software). When relevant, descriptive statistics were calculated separately for the spring-early summer period and late summer-fall period (see Table 1).

\section{Results}

\subsection{General conditions in the sampling area}

Unless stated otherwise, the descriptions below refer to all data from 2005 to 2008. When appropriate, separate results are reported for the subset of stations where $\mathrm{C}$ and $\mathrm{N}$ uptake rates were measured (hereafter termed "experimental stations") in order to demonstrate that sub-sampling was representative of the whole data set. Distinct SCM were present at $81 \%$ of the 465 stations analyzed (Fig. 1; see Martin et al., 2010 for a discussion of the other stations where chl $a$ was maximum at the surface or vertically homogenous). The depth of the SCM ranged from 4 to $114 \mathrm{~m}$ with a mean of $35 \pm 16 \mathrm{~m}$ (at experimental stations the range was 11$75 \mathrm{~m}$ and the mean $36 \pm 15 \mathrm{~m}$ ). The vertical position of the SCM matched the depth of the nitracline (mean $=38 \pm 16 \mathrm{~m}$ for all stations and $40 \pm 17 \mathrm{~m}$ for experimental ones) within $\pm 10 \mathrm{~m}$ in $79 \%$ (67\% for experimental stations) of the cases and within $\pm 20 \mathrm{~m}$ in $89 \%$ (88\% for experimental stations $)$ of cases $\left(Z_{\mathrm{SCM}}=1.00 \times Z_{\text {nitracline }}-2.57, r^{2}=0.46\right.$, $p<0.0001$ for all stations; $Z_{\mathrm{SCM}}=1.12 \times Z_{\text {nitracline }}-9.24$, $r^{2}=0.41, \quad p<0.0001$ for experimental stations). Primary maxima of $\mathrm{NO}_{2}^{-}(\mathrm{PNM})$ and $\mathrm{NH}_{4}^{+}(\mathrm{PAmM})$ were widespread (not shown but see Martin et al., 2010), and their vertical positions were significantly correlated with the SCM $\left(Z_{\mathrm{PNM}}=0.50 \times Z_{\mathrm{SCM}}+39.23, r^{2}=0.12\right.$, $p<0.0001, n=201 ; \quad Z_{\mathrm{PAmM}}=0.72 \times Z_{\mathrm{SCM}}+25.75, \quad r^{2}=$ $0.20, p<0.0001, n=96)$.

$F_{v} / F_{m}$ was generally high at the surface and the SCM (not shown), with median values of 0.55 and 0.58 , respectively (see Martin et al., 2010). Although the overall data distribution was similar for the two sampling depths, a comparison of locally paired samples showed $F_{v} / F_{m}$ to be significantly higher at the SCM during spring-early summer (2008 expedition; Wilcoxon's signed-rank test, $p<0.001$ ). This difference was not apparent during late summer-fall (2005, 2006 and 2007 expeditions; $p=0.76$ ). 
Table 1. Characteristics of the SCM at experimental stations located in the coastal Beaufort Sea (CBS), offshore Beaufort Sea (OBS), Northwest Passage (NWP), western, central and eastern Baffin Bay (WBB, CBB and EBB, respectively) and Hudson Bay (HB) for springearly summer and late summer-fall. Stations where incubations were also performed with surface samples are marked with an asterisk $\left({ }^{*}\right)$, "n/d" indicates that no data were available and "_" stands for values below the limit of detection. Averages (AVG) and standard deviations (SD) are presented for each season.

\begin{tabular}{|c|c|c|c|c|c|c|c|c|c|c|c|c|c|}
\hline Region & Station & Date & $\begin{array}{l}\text { Day of } \\
\text { year }\end{array}$ & $\begin{array}{l}\text { Depth } \\
(\mathrm{m})\end{array}$ & $\begin{array}{c}{[\operatorname{chl} a]} \\
\left(\mu \mathrm{g} \mathrm{L}^{-1}\right)\end{array}$ & $\begin{array}{c}{\left[\mathrm{NO}_{3}^{-}\right]} \\
(\mu \mathrm{M})\end{array}$ & $\begin{array}{c}{\left[\mathrm{NO}_{2}^{-}\right]} \\
(\mu \mathrm{M})\end{array}$ & $\begin{array}{c}{\left[\mathrm{NH}_{4}^{+}\right]} \\
(\mu \mathrm{M})\end{array}$ & $\begin{array}{c}{[\text { Urea }]} \\
(\mu \mathrm{M})\end{array}$ & $\begin{array}{c}\text { Total N } \\
(\mu \mathrm{M})\end{array}$ & $\begin{array}{c}T \\
\left({ }^{\circ} \mathrm{C}\right)\end{array}$ & $\begin{array}{c}\% \text { of } E \text { at } \\
\text { surface }\end{array}$ & $\begin{array}{c}E_{\mathrm{SCM}} \\
\left(\mu \mathrm{mol} \text { quanta } \mathrm{m}^{-2} \mathrm{~s}^{-1}\right)\end{array}$ \\
\hline CBS & D43 ${ }^{1}$ & 28 Apr 2008 & 119 & 30 & 0.73 & 3.63 & 0.09 & 0.02 & - & 3.77 & -1.7 & 6.4 & 0.3 \\
\hline CBS & $1020 \mathrm{~A}$ & 6 May 2008 & 127 & 44 & 0.46 & 6.21 & 0.26 & 0.02 & - & 6.54 & -1.7 & 8.8 & 44 \\
\hline CBS & $405 b$ & 19 May 2008 & 140 & 16 & 8.31 & 0.00 & 0.10 & 0.05 & - & 0.15 & -1.0 & 16 & 62 \\
\hline CBS & 1011 & 21 May 2008 & 142 & 63 & 0.88 & 6.53 & 0.11 & 1.01 & - & 7.66 & -1.5 & 1.7 & 5.8 \\
\hline CBS & 1806 & 23 May 2008 & 144 & 50 & 4.47 & 7.53 & 0.11 & - & - & 7.65 & -1.4 & 4.3 & 18 \\
\hline CBS & 9008 & 27 May 2008 & 148 & 37 & 12.10 & 1.34 & 0.08 & - & - & 1.42 & -1.2 & 6.8 & 31 \\
\hline CBS & 405 & 1 Jun 2008 & 153 & 37 & 0.53 & 4.02 & 0.16 & 0.20 & - & 4.38 & -1.7 & 11 & 36 \\
\hline CBS & $\mathrm{F} 7^{1}$ & 8 Jun 2008 & 160 & 12 & 2.98 & 1.87 & 0.18 & 0.25 & 0.1 & 2.42 & -1.4 & 44 & 30 \\
\hline CBS & $405 b$ & 10 Jun 2008 & 162 & 37 & 0.84 & 2.32 & 0.19 & 0.10 & 0.1 & 2.75 & -1.2 & 4.8 & 30 \\
\hline CBS & $\mathrm{F} 7^{1}$ & 19 Jun 2008 & 171 & 33 & 9.57 & 5.00 & 0.16 & 0.35 & - & 5.52 & -1.4 & 4.7 & 1.6 \\
\hline CBS & $\mathrm{FB}_{07}{ }^{1}$ & 21 Jun 2008 & 173 & 37 & 4.42 & 1.16 & 0.14 & 0.16 & - & 1.53 & -1.3 & 2.7 & 9 \\
\hline CBS & 1216 & 23 Jun 2008 & 175 & 33 & 1.27 & 3.44 & 0.12 & 0.18 & - & 3.74 & -1.4 & 2.2 & 15 \\
\hline CBS & $\mathrm{F} 7^{1}$ & 24 Jun 2008 & 176 & 33 & 4.80 & 1.61 & 0.08 & 0.63 & - & 2.34 & -1.3 & 6.7 & 25 \\
\hline CBS & 1200 & 27 Jun 2008 & 179 & 36 & 1.52 & 0.80 & 0.16 & 0.09 & 0.1 & 1.18 & -1.2 & 2.7 & 17 \\
\hline CBS & 1208 & 28 Jun 2008 & 180 & 35 & 1.64 & 0.10 & 0.00 & - & 0.2 & 0.27 & -1.1 & 1.7 & 11 \\
\hline OBS & 421 & 1 Jul 2008 & 183 & 62 & 3.55 & 0.79 & 0.08 & 0.08 & - & 0.96 & -1.2 & 2.8 & 20 \\
\hline CBS & 6006 & 4 Jul 2008 & 186 & 54 & 7.55 & 4.55 & 0.20 & 0.06 & 0.2 & 5.05 & -1.3 & 2.0 & 12 \\
\hline CBS & 2010 & 6 Jul 2008 & 188 & 29 & 0.37 & 3.89 & 0.14 & 0.04 & 0.2 & 4.25 & -1.5 & 5.9 & 30 \\
\hline CBS & 410 & 8 Jul 2008 & 190 & 54 & 1.25 & 3.54 & $\mathrm{n} / \mathrm{d}$ & 0.26 & - & 3.80 & -1.5 & 4.6 & 28 \\
\hline \multirow[t]{2}{*}{ CBS } & 416 & $10 \mathrm{Jul} 2008$ & 192 & 73 & 4.52 & 6.77 & 0.14 & 0.19 & - & 7.10 & -1.4 & 0.9 & 5.4 \\
\hline & & & $\begin{array}{l}A V G \\
(S D)\end{array}$ & $\begin{array}{c}40 \\
(15)\end{array}$ & $\begin{array}{c}3.59 \\
(3.42)\end{array}$ & $\begin{array}{c}3.26 \\
(2.32)\end{array}$ & $\begin{array}{c}0.13 \\
(0.06)\end{array}$ & $\begin{array}{c}0.22 \\
(0.25)\end{array}$ & $\begin{array}{c}0.15 \\
(0.05)\end{array}$ & $\begin{array}{c}3.62 \\
(2.40)\end{array}$ & $\begin{array}{l}-1.4 \\
(0.2)\end{array}$ & $\begin{array}{c}7.0 \\
(9.3)\end{array}$ & $\begin{array}{c}23 \\
(15)\end{array}$ \\
\hline EBB & BA01-05 & 16 Aug 2005 & 228 & 24 & 0.88 & 0.28 & 0.08 & 0.05 & $\mathrm{n} / \mathrm{d}$ & 0.41 & 0.0 & 9.2 & 12 \\
\hline WBB & BA03-05 & 18 Aug 2005 & 230 & 42 & 2.14 & 0.07 & 0.06 & - & $\mathrm{n} / \mathrm{d}$ & 0.13 & 1.9 & 0.5 & 1.3 \\
\hline $\mathrm{CBB}$ & BA04-05 & 22 Aug 2005 & 234 & 25 & 1.05 & 5.34 & 0.30 & - & $\mathrm{n} / \mathrm{d}$ & 5.64 & -1.4 & 10 & 24 \\
\hline NWP & $\mathrm{S} 3$ & 23 Aug 2005 & 235 & 33 & 3.45 & 2.73 & 0.12 & 0.33 & $\mathrm{n} / \mathrm{d}$ & 3.18 & -0.7 & 4.8 & 4.0 \\
\hline NWP & S4 & 24 Aug 2005 & 236 & 29 & 6.38 & 0.49 & 0.09 & 0.39 & $\mathrm{n} / \mathrm{d}$ & 0.97 & -1.1 & 4.4 & 7.9 \\
\hline CBS & S201 & 2 Sep 2005 & 245 & 19 & 0.79 & 1.13 & 0.10 & 0.41 & $\mathrm{n} / \mathrm{d}$ & 1.64 & 0.4 & 3.6 & 7.9 \\
\hline OBS & $\mathrm{S} 10$ & 5 Sep 2005 & 248 & 52 & 0.41 & 2.34 & 0.12 & 0.14 & $\mathrm{n} / \mathrm{d}$ & 2.60 & -1.0 & 9.3 & 20 \\
\hline CBS & CA08-05 & 9 Sep 2005 & 252 & 43 & 0.41 & 0.70 & 0.10 & - & $\mathrm{n} / \mathrm{d}$ & 0.80 & -0.2 & 8.1 & 12 \\
\hline CBS & CA180-05 & 12 Sep 2005 & 255 & 30 & 2.70 & 4.82 & 0.22 & 0.11 & $\mathrm{n} / \mathrm{d}$ & 5.15 & -1.1 & 4.4 & 8.0 \\
\hline $\mathrm{HB}$ & $\mathrm{S} 22$ & 6 Oct 2005 & 279 & 35 & 0.83 & 0.70 & 0.09 & 0.04 & $\mathrm{n} / \mathrm{d}$ & 0.83 & -1.4 & 2.5 & 1.3 \\
\hline $\mathrm{HB}$ & NR24 & 10 Oct 2005 & 283 & 17 & 1.35 & 1.03 & 0.08 & 0.25 & $\mathrm{n} / \mathrm{d}$ & 1.36 & 5.1 & 0.8 & 1.9 \\
\hline CBB & $132 *$ & 9 Sep 2006 & 252 & 34 & 0.32 & 4.03 & 0.09 & 0.34 & $\mathrm{n} / \mathrm{d}$ & 4.46 & -1.4 & 2.4 & 1.2 \\
\hline EBB & $131^{*}$ & 11 Sep 2006 & 254 & 35 & 0.62 & 4.84 & 0.23 & 0.47 & $\mathrm{n} / \mathrm{d}$ & 5.54 & -0.2 & 1.3 & 2.4 \\
\hline WBB & 118 & 14 Sep 2006 & 257 & 50 & 1.84 & 1.23 & 0.07 & 0.12 & $\mathrm{n} / \mathrm{d}$ & 1.42 & -1.2 & 0.1 & 0.1 \\
\hline $\mathrm{CBB}$ & $108^{*}$ & 17 Sep 2006 & 260 & 40 & 1.50 & 2.32 & 0.11 & 0.34 & $\mathrm{n} / \mathrm{d}$ & 2.77 & 0.7 & 0.9 & 1.4 \\
\hline NWP & $303^{*}$ & 21 Sep 2006 & 264 & 22 & 1.36 & 2.34 & 0.06 & 0.64 & $\mathrm{n} / \mathrm{d}$ & 3.04 & 0.2 & 12 & 20 \\
\hline NWP & $307^{*}$ & 23 Sep 2006 & 266 & 31 & 0.16 & 5.47 & 0.12 & 0.63 & $\mathrm{n} / \mathrm{d}$ & 6.22 & -1.3 & 9.1 & 12 \\
\hline CBS & $405^{*}$ & 1 Oct 2006 & 274 & 48 & 0.67 & 8.30 & 0.47 & 0.30 & $\mathrm{n} / \mathrm{d}$ & 9.07 & -1.3 & 0.8 & 0.8 \\
\hline CBS & $408^{*}$ & 3 Oct 2006 & 276 & 67 & 0.32 & 7.13 & 0.27 & 0.09 & $\mathrm{n} / \mathrm{d}$ & 7.49 & -1.3 & 2.1 & 2.1 \\
\hline CBS & SH (409)* & 4 Oct 2006 & 277 & 35 & 0.47 & 0.19 & 0.09 & 0.25 & $\mathrm{n} / \mathrm{d}$ & 0.53 & 0.4 & 2.2 & 2.4 \\
\hline CBS & 436 & 9 Oct 2006 & 282 & 18 & 0.65 & 0.03 & 0.07 & 0.04 & $\mathrm{n} / \mathrm{d}$ & 0.14 & 0.4 & 11 & 3.0 \\
\hline CBS & $435^{*}$ & 12 Oct 2006 & 285 & 55 & 0.16 & 3.69 & 0.20 & 0.03 & $\mathrm{n} / \mathrm{d}$ & 3.92 & -1.2 & 3.3 & 1.5 \\
\hline CBS & 407 & 18 Oct 2006 & 291 & 30 & 0.70 & 0.88 & 0.15 & 0.13 & $\mathrm{n} / \mathrm{d}$ & 1.16 & -0.5 & 2.6 & 0.9 \\
\hline WBB & 101 & 29 Sep 2007 & 272 & 41 & 0.31 & 1.66 & 0.00 & 0.79 & $\mathrm{n} / \mathrm{d}$ & 2.45 & -1.6 & 1.4 & $\mathrm{n} / \mathrm{d}$ \\
\hline EBB & 115 & 1 Oct 2007 & 274 & 80 & 0.13 & 10.6 & 0.12 & - & - & 10.73 & -0.8 & 0.001 & $\mathrm{n} / \mathrm{d}$ \\
\hline $\mathrm{CBB}$ & 108 & 3 Oct 2007 & 276 & 30 & 5.62 & 2.22 & 0.03 & 0.35 & - & 2.61 & -0.6 & 3.4 & $\mathrm{n} / \mathrm{d}$ \\
\hline NWP & 302 & 7 Oct 2007 & 280 & 37 & 0.24 & 0.63 & 0.03 & 0.51 & - & 1.17 & 0.4 & 6.1 & $\mathrm{n} / \mathrm{d}$ \\
\hline CBS & 435 & 17 Oct 2007 & 290 & 16 & 0.24 & 1.85 & 0.02 & 0.29 & - & 2.16 & -0.9 & 24 & 6.1 \\
\hline CBS & 1806 & 19 Oct 2007 & 292 & 22 & 0.33 & 0.00 & 0.02 & 0.02 & - & 0.04 & -0.8 & 17 & 1.7 \\
\hline CBS & 408 & 22 Oct 2007 & 295 & 12 & 0.65 & 0.51 & 0.15 & 0.32 & $\mathrm{n} / \mathrm{d}$ & 0.98 & -1.1 & 22 & 3.3 \\
\hline CBS & 407 & 23 Oct 2007 & 296 & 34 & 0.70 & 2.28 & 0.14 & 0.34 & $\mathrm{n} / \mathrm{d}$ & 2.76 & -1.3 & 4.1 & 0.4 \\
\hline CBS & 405 & 25 Oct 2007 & 298 & 31 & 0.23 & 0.47 & 0.06 & 0.17 & $\mathrm{n} / \mathrm{d}$ & 0.70 & -0.7 & 6.0 & 0.8 \\
\hline \multirow[t]{2}{*}{ CBS } & 1116 & 28 Oct 2007 & 301 & 7 & 0.23 & 7.10 & 0.31 & 0.46 & - & 7.89 & -1.5 & 47 & 12 \\
\hline & & & $\begin{array}{l}A V G \\
(S D)\end{array}$ & $\begin{array}{c}34 \\
(15)\end{array}$ & $\begin{array}{c}1.15 \\
(1.47)\end{array}$ & $\begin{array}{c}2.65 \\
(2.70)\end{array}$ & $\begin{array}{c}0.13 \\
(0.10)\end{array}$ & $\begin{array}{c}0.29 \\
(0.20)\end{array}$ & $\begin{array}{l}- \\
(-)\end{array}$ & $\begin{array}{c}3.03 \\
(2.79)\end{array}$ & $\begin{array}{l}-0.5 \\
(1.3)\end{array}$ & $\begin{array}{c}7.2 \\
(9.3)\end{array}$ & $\begin{array}{c}5.9 \\
(6.6)\end{array}$ \\
\hline
\end{tabular}

\footnotetext{
${ }^{1} E_{\mathrm{SCM}}$ corrected for the presence of ice.
} 

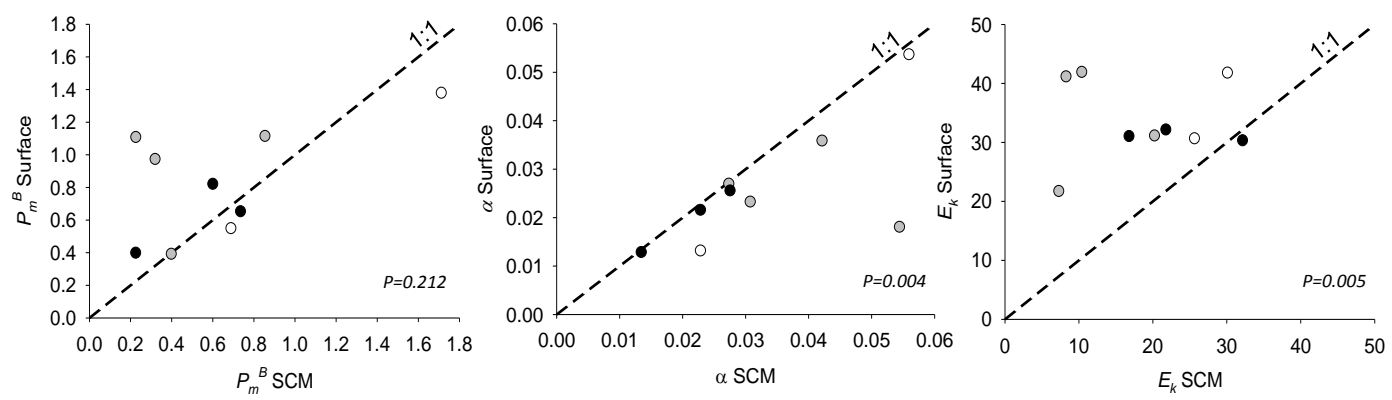

Fig. 2. Comparison of photosynthesis-irradiance parameters $\left(P_{m}^{B}, \alpha\right.$ and $\left.E_{k}\right)$ between the surface and the SCM in Baffin Bay (black), the Canadian Archipelago (white) and the Beaufort Sea (gray). The level of significance $(p)$ for the difference between paired samples is given in each panel.

Table 1 provides the details of physical and chemical properties at $Z_{\mathrm{SCM}}$ for experimental stations. Temperature ranged from -1.7 to $5.1{ }^{\circ} \mathrm{C}$ and exceeded $0{ }^{\circ} \mathrm{C}$ in only $17 \%$ of cases. Daily averaged irradiance varied between 0.1 and $62 \mu \mathrm{mol}$ quanta $\mathrm{m}^{-2} \mathrm{~s}^{-1}$ across stations (overall mean of $13 \pm 13 \mu$ mol quanta $\mathrm{m}^{-2} \mathrm{~s}^{-1}$ ), representing 0.001 to $47 \%$ of incident irradiance at the surface (mode in the $1-10 \%$ range for $68 \%$ of stations). Concentrations of $\mathrm{NO}_{3}^{-}$ranged from the limit of detection to $10.6 \mu \mathrm{M}$ but were generally lower than $2 \mu \mathrm{M}$ (47\% of stations), whereas $\mathrm{NH}_{4}^{+}$concentrations ranged from the limit of detection to $1.0 \mu \mathrm{M}$, with values below $0.2 \mu \mathrm{M}$ at $55 \%$ of stations. The concentrations of $\mathrm{NO}_{2}^{-}$ and urea remained relatively low. Overall, $99 \%$ of the variability in the concentration and $78 \pm 24 \%$ of the total amount of inorganic $\mathrm{N}$ (i.e., $\mathrm{NO}_{3}^{-}+\mathrm{NO}_{2}^{-}+\mathrm{NH}_{4}^{+}$) at the $\mathrm{SCM}$ were due to $\mathrm{NO}_{3}^{-}$.

\subsection{Difference in uptake-irradiance parameters between surface and SCM communities}

At stations where incubations were performed simultaneously (see Table 1) with surface and SCM samples, $P_{m}^{B}$ did not differ significantly between the two communities (Fig. 2; $n=9$, paired t-test $p=0.212$ ), whose mean values were $0.82 \pm 0.35$ and $0.64 \pm 0.46 \mu \mathrm{gC}$ $(\mu \mathrm{g} \text { chl } a)^{-1} \mathrm{~h}^{-1}$, respectively. However, $\alpha$ was significantly lower at surface than at the SCM (Fig. 2; mean of $0.026 \pm 0.013$ versus $0.033 \pm 0.015 \mu \mathrm{gC}(\mu \mathrm{g} \text { chl } a)^{-1} \mathrm{~h}^{-1}$ $\left(\mu \text { mol quanta } \mathrm{m}^{-2} \mathrm{~s}^{-1}\right)^{-1}$; Wilcoxon's signed-rank test $p<0.01$ ), driving a decrease in $E_{k}$ with depth (Fig. 2; mean of $33 \pm 7 \mu$ mol quanta $\mathrm{m}^{-2} \mathrm{~s}^{-1}$ at the surface and $19 \pm 9 \mu$ mol quanta $\mathrm{m}^{-2} \mathrm{~s}^{-1}$ at the SCM; paired t-test $p<0.01)$. Photoinhibition was observed only at the $\mathrm{SCM}$, for which $\beta$ varied between 0 and $0.0006 \mu \mathrm{g}$ $(\mu \mathrm{g} \mathrm{chl} a)^{-1} \mathrm{~h}^{-1}$ ( $\mu$ mol quanta $\left.\mathrm{m}^{-2} \mathrm{~s}^{-1}\right)^{-1}$ (data not shown).

The $N_{m}^{B}\left(\mathrm{NO}_{3}\right)$ (not shown) was clearly lower at the surface than at the SCM (mean of $0.018 \pm 0.022$ and $0.031 \pm 0.021 \mu \mathrm{gN} \quad(\mu \mathrm{gchl} a)^{-1} \mathrm{~h}^{-1}$, respectively; $n=8$; paired t-test $p<0.05$ ). However, $\alpha_{\left(\mathrm{NO}_{3}\right)}$ (mean of $0.001 \pm 0.002$ versus $0.003 \pm 0.003 \mu \mathrm{g} \mathrm{N}(\mu \mathrm{g} \mathrm{chl} a)^{-1} \mathrm{~h}^{-1}$
( $\mu$ mol quanta $\left.\mathrm{m}^{-2} \mathrm{~s}^{-1}\right)^{-1}$ ) and $E_{k}\left(\mathrm{NO}_{3}\right)$ (mean of $18 \pm 14$ versus $15 \pm 9 \mu$ mol quanta $\mathrm{m}^{-2} \mathrm{~s}^{-1}$ ) were not significantly different (Wilcoxon's signed-rank test $p=0.578$ and 0.844 , respectively).

In order to assess the contribution of the SCM layer (defined as the zone between the top of the SCM - i.e., the first depth where the mean vertical gradient of in vivo fluorescence was zero over 5 consecutive depth bins - and the bottom of the euphotic zone, set here as the depth of the $0.1 \%$ of surface irradiance) to daily primary production and $\mathrm{NO}_{3}^{-}$ uptake during 2006, we combined uptake-irradiance parameters with measurements of daily mean irradiance and detailed vertical profiles of $\operatorname{chl} a$ reconstructed from calibrated in vivo fluorescence. A specific example is given in Fig. 3 for station 303, which is representative of mean conditions for this data set (see yellow arrow in Fig. 1). In this case, we prescribed the uptake-irradiance parameters of the surface community between 0 and $14 \mathrm{~m}$ (which coincidentally matched the depth of the pycnocline at this station) and those of the SCM from 14 to $71 \mathrm{~m}$ (based on the fact that $N_{m}^{B}\left(\mathrm{NO}_{3}\right)$ varied with neither ambient $\mathrm{NO}_{3}^{-}$concentrations nor experimental enrichment; see Sect. 3.7 and Table A2).

We observed that the SCM layer mediated 43 to $76 \%$ of $\mathrm{C}$ uptake (mean $=62 \pm 11 \%$ ) and 64 to $98 \%$ of $\mathrm{NO}_{3}^{-}$ uptake (mean $=80 \pm 12 \%$ ) in the euphotic zone. For instance, at station 303 (a station representative of mean conditions for the entire data set; yellow arrow in Fig. 1), maximum primary production $\left(15.67 \mu \mathrm{g} \mathrm{L} \mathrm{L}^{-1} \mathrm{~d}^{-1}\right)$ and $\mathrm{NO}_{3}^{-}$ uptake $\left(1.55 \mu \mathrm{g} \mathrm{NL}^{-1} \mathrm{~d}^{-1}\right)$ occurred at $20 \mathrm{~m}$ and coincided with the SCM $\left(1.64 \mu \mathrm{gchl} a \mathrm{~L}^{-1}\right.$; Fig. 3). Vertical integration over the two vertical horizons gave a production of $36.35 \mu \mathrm{g} \mathrm{L}^{-1} \mathrm{~d}^{-1}$ and $\mathrm{NO}_{3}^{-}$uptake of $2.00 \mu \mathrm{g} \mathrm{N} \mathrm{L}^{-1} \mathrm{~d}^{-1}$ for the surface layer (representing 24 and $13 \%$ of the total, respectively) and $\mathrm{C}$ production and $\mathrm{NO}_{3}^{-}$uptake of $112.40 \mu \mathrm{g} \mathrm{CL}^{-1} \mathrm{~d}^{-1}$ (76\% of the total) and $13.44 \mu \mathrm{g} \mathrm{N} \mathrm{L}^{-1} \mathrm{~d}^{-1}$ (87\% of the total) for the SCM layer. 


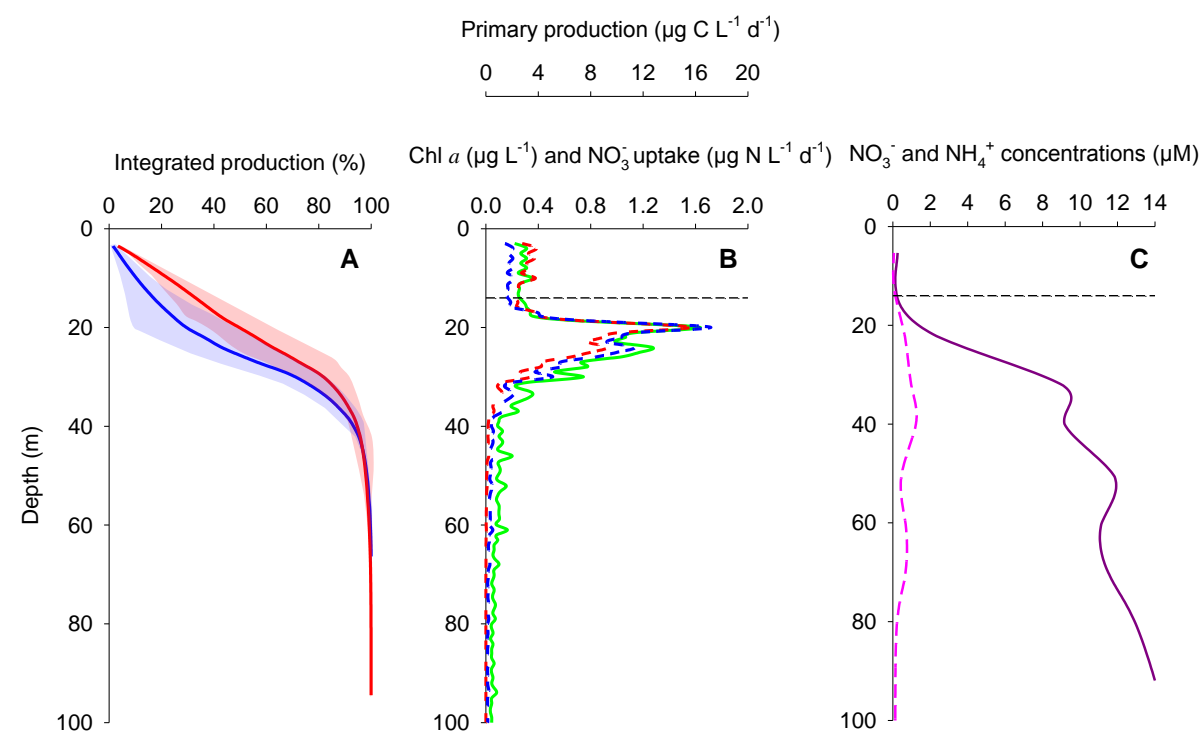

Fig. 3. Reconstructed profiles of (A) averaged integrated production (\% of total water-column production; standard deviation delimited by the shaded areas) for $\mathrm{C}$ uptake (red) and $\mathrm{N}$ uptake (blue) for incubations performed simultaneously with surface and SCM samples, (B) chl $a$ concentration estimated from post-calibrated in-vivo fluorescence $\left(\mu \mathrm{g} \mathrm{L} \mathrm{L}^{-1}\right.$; solid green line) and primary production $\left(\mu \mathrm{g} \mathrm{CL}^{-1} \mathrm{~d}^{-1}\right.$; red dashed line) and $\mathrm{NO}_{3}^{-}$uptake $\left(\mu \mathrm{g} \mathrm{N} \mathrm{L}^{-1} \mathrm{~d}^{-1}\right.$; blue dashed line) estimated from uptake-irradiance parameters and (C) $\mathrm{NO}_{3}^{-}$(solid purple line) and $\mathrm{NH}_{4}^{+}$(pink dashed line) concentrations $(\mu \mathrm{M}$ ) for station 303 in 2006 (yellow arrow in Fig. 1; left-hand side). The black dashed line marks the depth of the pycnocline $(14 \mathrm{~m})$.

\subsection{Photosynthetic parameters at the SCM under trace ${ }^{15} \mathrm{~N}$ additions}

A larger set of experiments was performed with water from the SCM only (excluding results obtained from incubations performed simultaneously with surface and SCM; see Table 1) collected during late summer-fall (2005 to 2007) and spring-early summer (2008). For a given station, photosynthetic parameters were derived using data from all incubators since no significant effect of $\mathrm{N}$ substrate on $\mathrm{C}$ uptake was observed. The $P_{m}^{B}$ in units of $\mu \mathrm{gC}(\mu \mathrm{gchl} a)^{-1} \mathrm{~h}^{-1}$ ranged from 0.07 to 2.77 (mean $=0.65 \pm 0.45$; Fig. 4). The parameter $\alpha$ in units of $\mu \mathrm{gC}(\mu \mathrm{gchl} a)^{-1} \mathrm{~h}^{-1}\left(\mu \mathrm{mol} \text { quanta } \mathrm{m}^{-2} \mathrm{~s}^{-1}\right)^{-1}$ ranged from 0.006 to 0.078 (mean $=0.027 \pm 0.014$; Fig. 4). Corresponding $E_{k}$ values in units of $\mu$ molquanta $\mathrm{m}^{-2} \mathrm{~s}^{-1}$ varied between 7 and 97 (mean $=24 \pm 13$; Fig. 4). The $\beta$ parameter (same units as $\alpha$ ) was significant at only $12 \%$ of the stations, with values ranging from 0.00002 to 0.0032 (mean $=0.0010 \pm 0.0008$; data not shown).

\subsection{Nitrogen uptake by SCM communities under trace ${ }^{15} \mathrm{~N}$ additions}

Nitrate uptake was highly variable among stations $(n=53$; Appendix $\mathrm{B})$. The mean values for uptakeirradiance parameters were $0.042 \pm 0.043 \mu \mathrm{g} \mathrm{N}$ $\left(\begin{array}{ll}\mu \mathrm{gchl} & a\end{array}\right)^{-1} \mathrm{~h}^{-1}$ for $N_{m\left(\mathrm{NO}_{3}\right)}^{B}, \quad 0.004 \pm 0.007 \quad(\mu \mathrm{g} \mathrm{N}$ $\left.(\mu \mathrm{gchl} a)^{-1} \mathrm{~h}^{-1}\left(\mu \mathrm{mol} \text { quanta } \mathrm{m}^{-2} \mathrm{~s}^{-1}\right)^{-1}\right)$ for $\alpha_{\left(\mathrm{NO}_{3}\right)}$,
$18 \pm 12 \mu$ mol quanta $\mathrm{m}^{-2} \mathrm{~s}^{-1}$ for $E_{k}\left(\mathrm{NO}_{3}\right)$ and $0.010 \pm 0.030$ for $D_{\left(\mathrm{NO}_{3}\right)}^{B}$ (same unit as $N_{m}^{B}$ ) representing $14 \pm 17 \%$ of the total uptake $\left(N_{m}^{B}+D^{B}\right)$. Nitrite uptake was an order of magnitude lower (mean $N_{m}^{B}\left(\mathrm{NO}_{2}\right)=0.005$; mean $\alpha_{\left(\mathrm{NO}_{2}\right)}=0.0007$; mean $E_{k}\left(\mathrm{NO}_{2}\right)=11$; mean $\left.D_{\left(\mathrm{NO}_{2}\right)}^{B}=0.001 ; n=3\right)$. For $\mathrm{NH}_{4}^{+}$ uptake $\left(n=32 ;\right.$ Appendix B), $N_{m\left(\mathrm{NH}_{4}\right)}^{B}=0.016 \pm 0.017$, $\alpha_{\left(\mathrm{NH}_{4}\right)}=0.005 \pm 0.008$ and $E_{k}\left(\mathrm{NH}_{4}\right)=7 \pm 8$. Dark uptake $\left(\mathrm{NH}_{4}\right)=0.008 \pm 0.009$ and accounted for $26 \pm 24 \%$ of the total uptake. Urea uptake-irradiance incubations were also performed, but data will not be shown here since only 2 out of 8 stations had detectable responses and in situ urea concentrations were most often below the limit of detection.

\subsection{Relationships between environmental factors and uptake-irradiance parameters under $\operatorname{trace}^{15} \mathrm{~N}$ additions}

The PPMC analysis showed a strong correlation between $P_{m}^{B}, E_{k}$ and in situ temperature at SCM depth (correlation coefficient for $P_{m}^{B}$ between 0.62 and 0.97 across incubation sets, $p<0.0001$ and for $E_{k}$ between 0.72 and 0.88 , $p<0.0001$; Appendix A). Note that for the SCM this correlation was strongly influenced by station NR24, which was near the Nelson River and showed anomalously high temperature $\left(5.1^{\circ} \mathrm{C}\right)$. The day of year (DY) was significantly related to $N_{m}^{B}\left(\mathrm{NO}_{3}\right)$ uptake. No correlation was observed between $E_{k}$ and daily averaged irradiance at the SCM $\left(E_{\mathrm{SCM}}\right)$. For surface samples, the $E_{k}$ and $\alpha$ for $\mathrm{C}$ and $\mathrm{N}$ uptake showed 

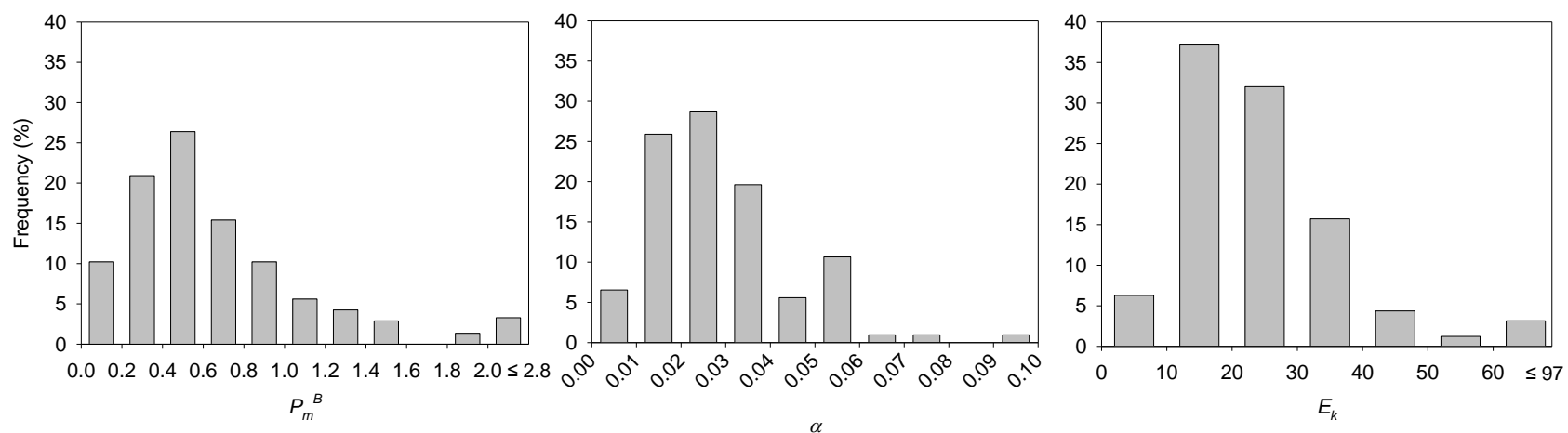

Fig. 4. Relative frequency distribution of photosynthesis-irradiance parameters at the SCM.

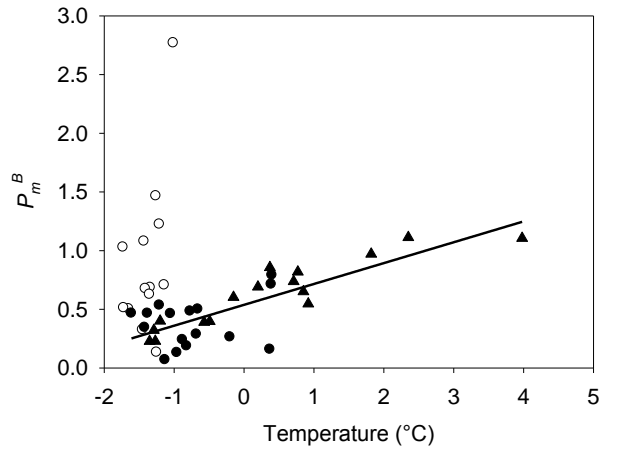

Fig. 5. Relationships between $P_{m}^{B}$ and in situ temperature for spring-early summer (open symbols) and late summer-fall (solid symbols) for surface (triangles) and SCM (circles) communities. The line represents the linear regression for late summer-fall data set.

a strong correlation with both $\mathrm{NH}_{4}^{+}$and total inorganic $\mathrm{N}$ concentrations (Table A2). A weak negative correlation was observed between $\alpha$ of $\mathrm{C}$ uptake and $\mathrm{NO}_{2}^{-}$concentrations and positive between $\alpha$ and $\mathrm{NH}_{4}^{+}$concentrations. At the SCM, strong positive relationships were observed between $N_{m}^{B}\left(\mathrm{NO}_{3}\right.$ and $\left.\mathrm{NH}_{4}\right), \alpha_{\left(\mathrm{NO}_{3} \text { and } \mathrm{NH}_{4}\right)}$ and the concentrations of $\mathrm{NO}_{3}^{-}$and total dissolved $\mathrm{N}$ (Table A1). The only relationship observed with dark uptake (not shown) was a weak positive correlation between $E_{\mathrm{SCM}}$ and $D_{\left(\mathrm{NO}_{3}\right)}^{B}$ uptake (0.40, $p<0.05$ ).

When excluding outlying station NR24 (see above), a detailed analysis of $P_{m}^{B}$ versus in situ temperature (T) showed a significant, positive linear relationship during late summerfall (Fig. $5 ; P_{m}^{B}=0.178 T+0.538, r^{2}=0.64, p<0.0001$ ). No significant relationship with temperature was observed during spring-early summer when the temperature range was very narrow at the $\mathrm{SCM}$ (between -1.7 and $-1.0^{\circ} \mathrm{C}$ ). The predictive power of the relationship for the spring-early summer was increased by including both $T$ and DY in a multiple linear regression $\left(P_{m}^{B}=8.417-0.0229 \mathrm{DY}+2.742 T\right.$, $r^{2}=0.77, p<0.001$; not shown).
Estimates of $E_{\mathrm{SCM}}$ were lower than $E_{k}$ for C uptake at $47 \%$ of the experimental stations during spring-early summer and $85 \%$ of the stations during late summer-fall (Fig. 6). The same percentage $(85 \%)$ was observed for $\mathrm{NO}_{3}^{-}$uptake during late summer-fall, but not during spring-early summer when only $21 \%$ of $E_{\mathrm{SCM}}$ values were lower than $E_{k}\left(\mathrm{NO}_{3}\right)$. For $\mathrm{NH}_{4}^{+}$uptake, $E_{\mathrm{SCM}}$ was lower than $E_{k}\left(\mathrm{NH}_{4}\right)$ in only 11 and $29 \%$ of cases during the spring-early summer and late summer-fall periods, respectively.

\subsection{Contribution of $\mathrm{NO}_{3}^{-}$uptake to inorganic $\mathrm{N}$ uptake $(f$-ratio) at the SCM}

When excluding dark uptake $\left(D^{B}\right)$ from calculations, the average $f$-ratio estimated for the mean $E_{\mathrm{SCM}}$ during spring-early summer $\left(23 \mu \mathrm{mol}\right.$ quanta $\left.\mathrm{m}^{-2} \mathrm{~s}^{-1}\right)$ was $0.74 \pm 0.26$ (Fig. 7). During late summer-fall, the average $f$-ratio estimate was $0.37 \pm 0.20$ for a mean $E_{\mathrm{SCM}}$ of $6 \mu \mathrm{mol}$ quanta $\mathrm{m}^{-2} \mathrm{~s}^{-1}$ (Fig. 7). Despite the wide range of observed $E_{\mathrm{SCM}}$ during spring-early summer ( 0.3 to $62 \mu \mathrm{mol}$ quanta $\mathrm{m}^{-2} \mathrm{~s}^{-1}$ ), the mean $f$-ratio estimated from individual $f$-ratio-irradiance curves for all stations only varies from $0.65 \pm 0.31$ to $0.76 \pm 0.24$ (Fig. 7). For late summer-fall, the $E_{\mathrm{SCM}}$ varied between 0.1 and $24 \mu \mathrm{mol}$ quanta $\mathrm{m}^{-2} \mathrm{~s}^{-1}$, with corresponding $f$-ratios ranging from $0.28 \pm 0.18$ to $0.48 \pm 0.21$ (Fig. 7). The $f$-ratio did not co-vary with $E_{\mathrm{SCM}}$ but was positively related to ambient $\mathrm{NO}_{3}^{-}$concentration $\left(f\right.$-ratio $=0.1 \mathrm{NO}_{3}^{-}+0.3 ; r^{2}=0.61$, $p<0.0001)$. Adding $D^{B}$ to the calculation produced a modest but significant decrease $(p<0.001)$ of $9 \%$ in the mean $f$ ratio for both seasons (Fig. 7; $0.65 \pm 0.24$ and $0.28 \pm 0.16$ ). Over the range of incubation irradiances, the decrease in mean $f$-ratio imparted by the inclusion of $D^{B}$ in calculations varied from 17 to $8 \%$ (values for minimum and maximum irradiances, respectively) for spring-early summer and between 4 and $11 \%$ for late summer-fall (Fig. 7).

Most SCM showed a RPI for $\mathrm{NO}_{3}^{-}$below unity (range $0.14-0.95$ with $D^{B}$ and $0.16-1.03$ without $D^{B}$; Fig. 8). The RPI was strongly correlated to $\mathrm{NO}_{3}^{-}$concentration (PPMC; correlation coefficient $=0.80$ and $p<0.0001$ 

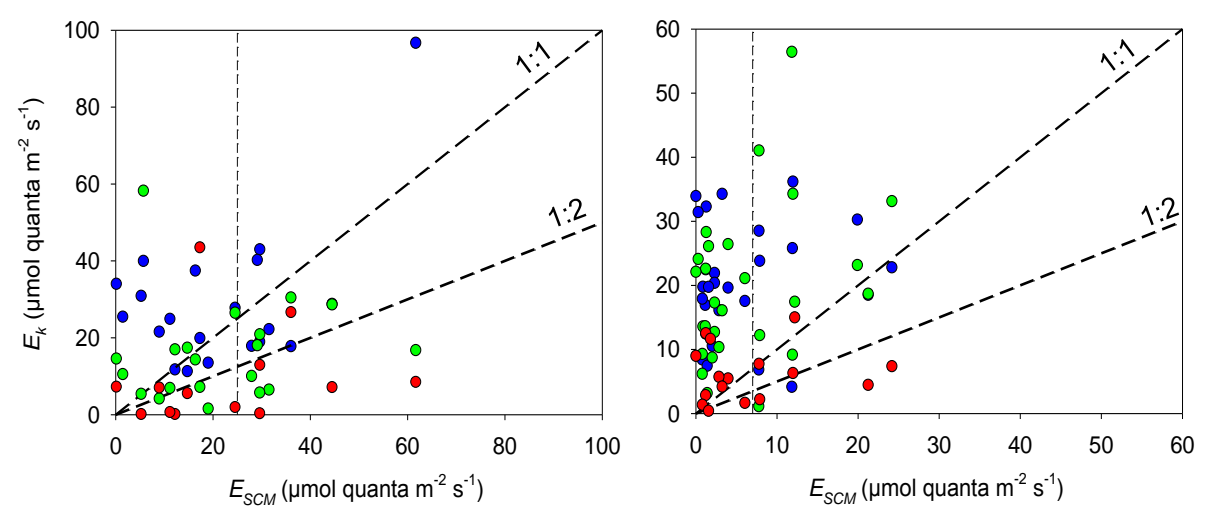

Fig. 6. Relationship between $E_{k}$ and $E_{\mathrm{SCM}}$ for photosynthesis (blue circles) and the uptake of $\mathrm{NO}_{3}^{-}$(green circles) and $\mathrm{NH}_{4}^{+}$(red circles) during spring-early summer (left-hand side) and late summer-fall (right-hand side). The dashed vertical lines represent the mean $E_{\mathrm{SCM}}$ for each season, and the dashed lines provide visual reference for $1: 1$ and $1: 2$ ratios.
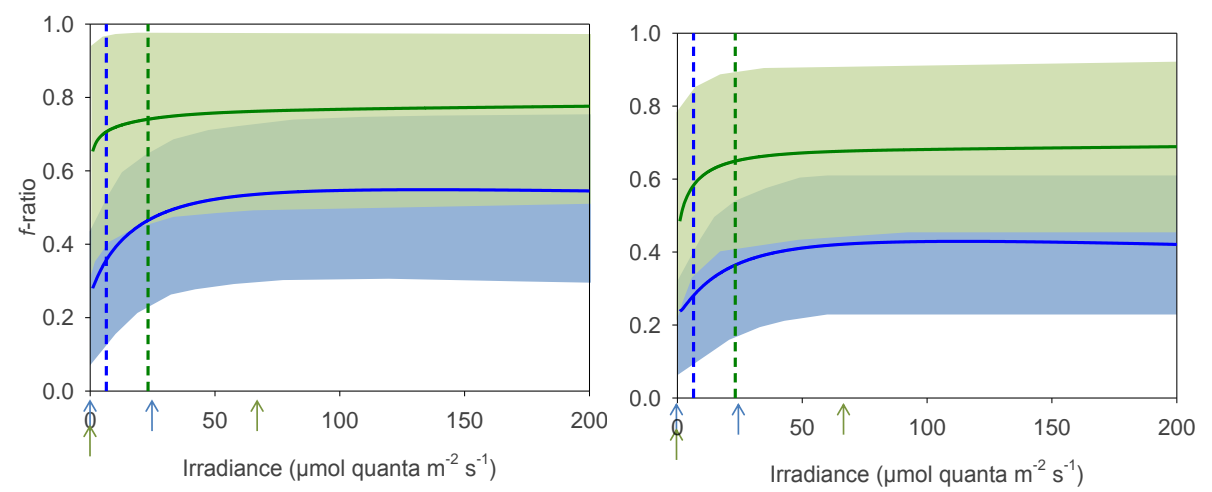

Fig. 7. Averages (solid lines) and ranges (shaded areas) of the $f$-ratio at the SCM as a function of incubation irradiance during spring-early summer (green) and late summer and early fall (blue), calculated with (right-hand side) or without (left-hand side) dark uptake $\left(D^{B}\right)$. Arrows and dashed lines give the range and mean of $E_{\mathrm{SCM}}$, respectively.

with DB included and correlation coefficient $=0.76$ and $p<0.0001$ without DB). Weak correlations were also observed between ESCM and the f-ratio (correlation coefficient $=0.40, p<0.05$ with or without DB) and the RPI (correlation coefficient $=0.40, p<0.05$ with or without $\mathrm{DB}$ ). A negative trend was observed between $\mathrm{NH}_{4}^{+}$concentration and RPI (Fig. 8), but this relationship was not significant $(p>0.05)$.

\subsection{Effect of $\mathbf{N}$ enrichment on uptake-irradiance parameters and their relationships with environmental variables}

Apart from a few anomalous data points, $\mathrm{N}$ enrichment had no significant overall effect $(p>0.05)$ on uptake-irradiance parameters for $\mathrm{C}$ (not shown), $\mathrm{NO}_{3}^{-}$and $\mathrm{NO}_{2}^{-}$(Fig. 9). Most of the apparent effects at individual stations (i.e., points away from the $1: 1$ line) disappeared when taking into account the standard error of the parameter estimates (errors bars were omitted to keep the graph legible). Only the $N_{m}^{B}\left(\mathrm{NH}_{4}\right)$ and $E_{k}\left(\mathrm{NH}_{4}\right)$ uptake were higher $(p<0.001)$ under enriched conditions. Most relationships observed between environmental variables and uptake parameters under trace ${ }^{15} \mathrm{~N}$ additions (Sect. 3.5) also held for the enriched treatments. Exceptions included the disappearance of relationships between $N_{m}^{B}\left(\mathrm{NO}_{3}\right.$ and $\left.\mathrm{NH}_{4}\right), \alpha_{\left(\mathrm{NO}_{3} \text { and } \mathrm{NH}_{4}\right)}$ and the concentrations of $\mathrm{NO}_{3}^{-}$and total dissolved $\mathrm{N}$ and the appearance of positive relationships between chl $a$ concentration and $N_{m}^{B}\left(\mathrm{NO}_{3}\right.$ and $\left.\mathrm{NH}_{4}\right)$ and $\alpha_{\left(\mathrm{NO}_{3} \text { and } \mathrm{NH}_{4}\right)}$ and between $E_{\mathrm{SCM}}$ and $N_{m\left(\mathrm{NO}_{3} \text { and } \mathrm{NH}_{4}\right)}^{B}$ and $E_{k\left(\mathrm{NH}_{4}\right)}($ Table A1).

\section{8 $\quad \mathrm{C}: \mathrm{N}$ stoichiometry at the SCM}

The $\mathrm{C}: \mathrm{N}$ uptake ratios (where $\mathrm{N}$ is the sum of $\mathrm{NH}_{4}^{+}$and $\mathrm{NO}_{3}^{-}$uptake) showed a general decrease with increasing inorganic $\mathrm{N}$ concentration (Fig. 10). The ratios at $E_{\mathrm{SCM}}$ $\left(P^{B}: N^{B}\right)$ were lower than at light-saturation $\left(P_{m}^{B}: N_{m}^{B}\right)$ and generally close to the Redfield value. The negative effect of $\mathrm{N}$ enrichment on the $\mathrm{C}: \mathrm{N}$ uptake ratio was strongest under experimental light saturation and rapidly vanished when $\mathrm{N}$ concentrations rose above $2 \mu \mathrm{M}$ (Fig. 10). 

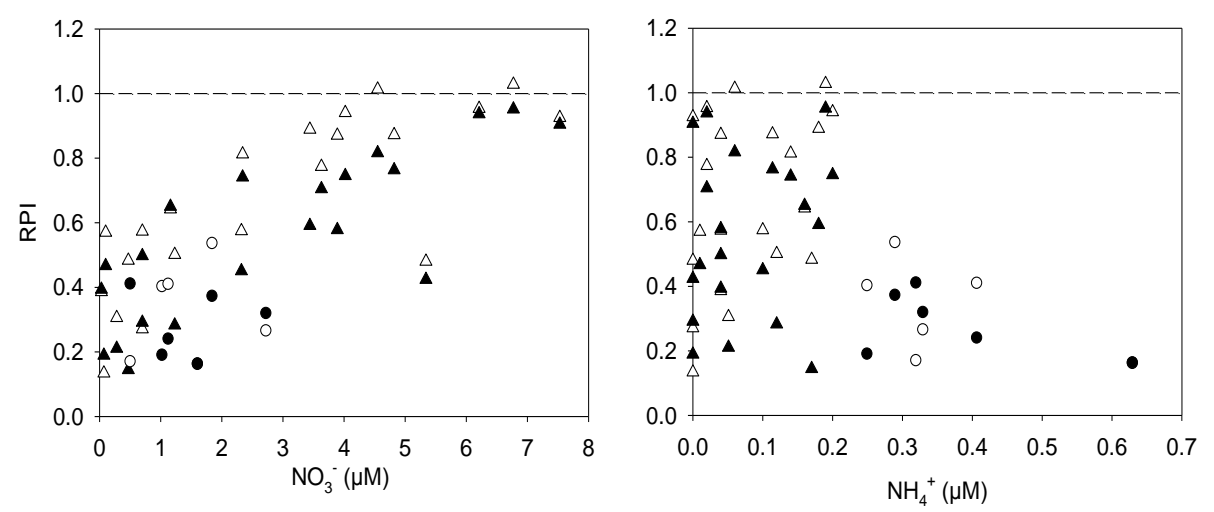

Fig. 8. Relationships between the ambient concentrations of $\mathrm{NO}_{3}^{-}$(left-hand side) or $\mathrm{NH}_{4}^{+}$(right-hand side) and the relative preference index (RPI) for $\mathrm{NO}_{3}^{-}$calculated with $D^{B}$ included (solid symbols) or not (open symbols) for $\mathrm{NH}_{4}^{+}$concentrations above (circles) and below or equal to (triangles) $0.2 \mu \mathrm{M}$.
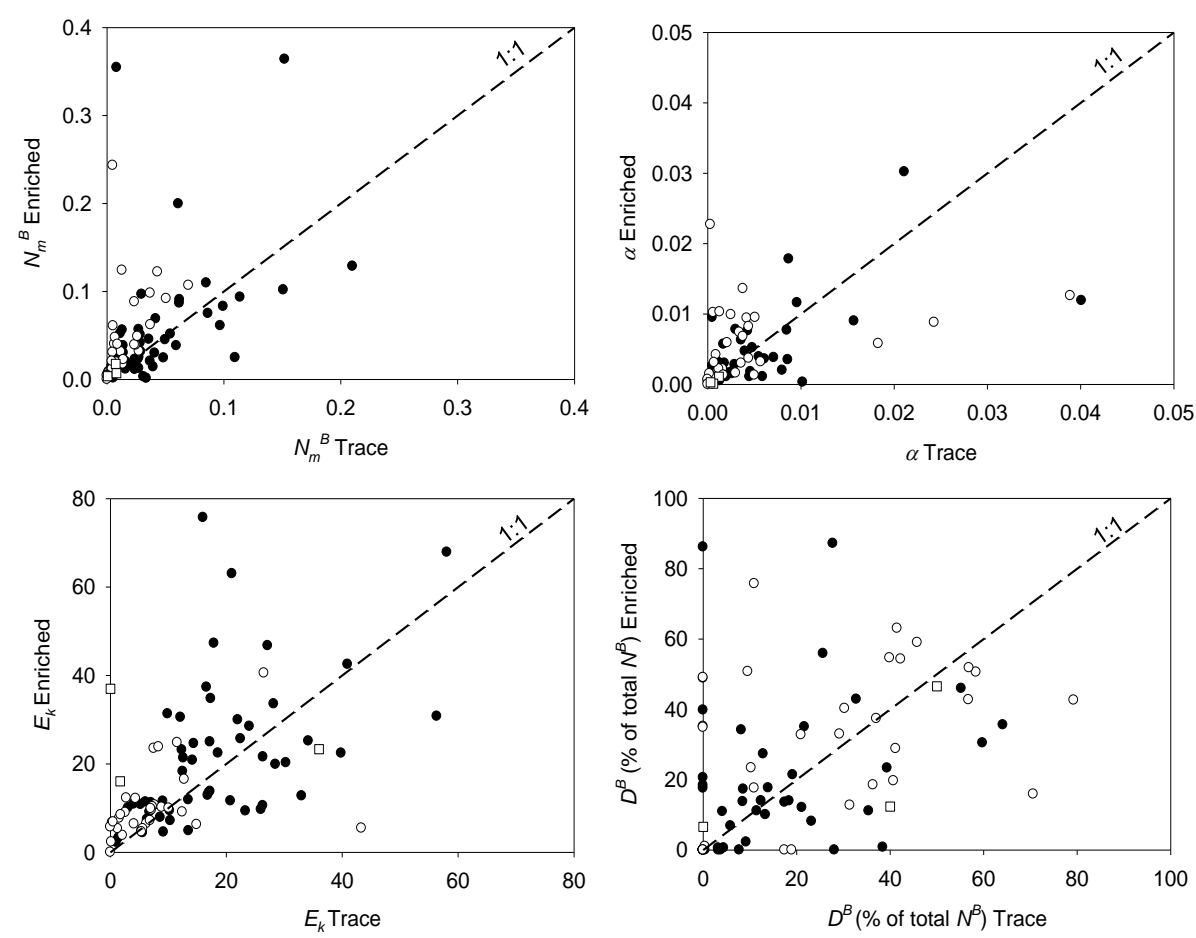

Fig. 9. Response of $N_{m}^{B}, \alpha, E_{k}$ and $D^{B}$ for $\mathrm{NO}_{3}^{-}$(solid circles), $\mathrm{NH}_{4}^{+}$(open circles), and $\mathrm{NO}_{2}^{-}$(open squares) uptake to experimental $\mathrm{N}$ enrichment during incubations (see Methods). The dashed $1: 1$ line represents a lack of response and is provided for visual reference. To ease the comprehension, the standard error is not presented in the graph (refer to "Sensor calibrations and data transformations" section).

\subsection{Post-incubation $\boldsymbol{F}_{v} / \boldsymbol{F}_{m}$}

For SCM phytoplankton, a significant negative correlation was observed between post-incubation $F_{v} / F_{m}$ and irradiance during the incubation (Fig. 11; $r=-0.64$, $p<0.0001, n=553) . F_{v} / F_{m}$ was stable (mean $\left.=0.62\right)$ up to ca. $30 \mu$ mol quanta $\mathrm{m}^{-2} \mathrm{~s}^{-1}$ and then declined with irradiance. All extreme low values $\left(F_{v} / F_{m}\right.$ below 0.3$)$ were measured in samples exposed to irradiance greater than $85 \mu$ mol quanta $\mathrm{m}^{-2} \mathrm{~s}^{-1}$ (representing on average $27 \%$ of incident irradiance at the surface). Post-incubation $F_{v} / F_{m}$ of surface phytoplankton $(5 \mathrm{~m}$; mean of $62 \%$ of incident irradiance measured at surface) also showed a significant negative correlation (Fig. 11; $r=-0.73, p<0.0001, n=48$ ), but extremely low values were not observed in the range of simulated irradiance. 

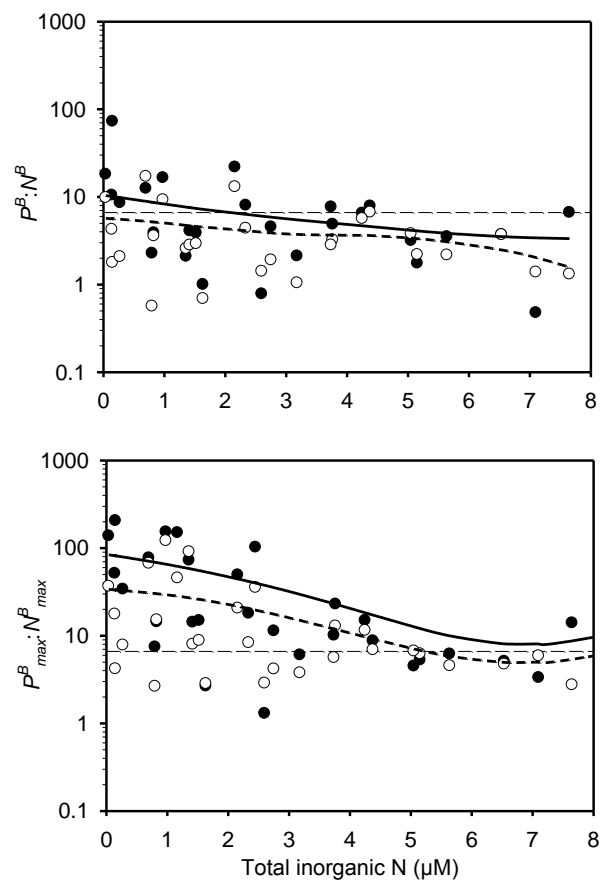

Fig. 10. Relationships between total inorganic $N$ and $C: N$ uptake ratios under trace (closed symbols) and enriched (open symbols) $\mathrm{N}$ additions at $E_{\mathrm{SCM}}$ (upper panel) and under saturating light conditions (bottom panel). Lines indicate the Redfield ratio (thin dashes) and moving averages for trace (solid) and enriched (dashes) conditions.

\section{Discussion}

This study provides the first assessment of combined $\mathrm{C}$ and $\mathrm{N}$ uptake by SCM communities over the entire swath of the Canadian Arctic and the full extent of the growth period (April to early November). It also extends recent observations showing that SCM are thriving, photosynthetically competent communities in the Arctic Ocean (Martin et al., 2010) and provides contemporary uptake-irradiance parameters to better tune models and remote-sensing algorithms of primary production. By distinguishing between the new and regenerated components of total primary production, our study addressed the biogeochemical significance of SCM communities for the food web and the biological $\mathrm{CO}_{2}$ pump.

Martin et al. (2010) hypothesized that the primary productivity of SCM communities was limited by irradiance due to their position in the lower euphotic zone near the nitracline. As a corollary, they further hypothesized that SCM depend principally on $\mathrm{NO}_{3}^{-}$and mediate a large share of water-column new production. Here we examine these hypotheses through a discussion of (1) the relative importance of dark versus light-dependent uptake for different $\mathrm{N}$ sources, (2) the photo-acclimation and stoichiometry of $\mathrm{C}$ and $\mathrm{N}$ uptake at low irradiance, and (3) the response of $\mathrm{C}$ and $\mathrm{N}$ uptake to environmental conditions in Canadian Arctic

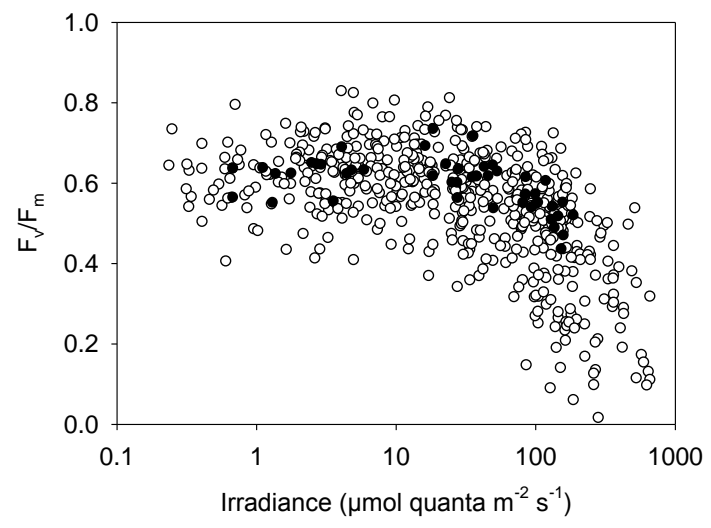

Fig. 11. Changes in $F_{v} / F_{m}$ after light-gradient incubations of SCM algae (open symbols) and surface algae (solid symbols).

waters. The discussion ends with a strategy for selecting uptake-irradiance parameters for models and remote-sensing algorithms.

\subsection{N nutrition and the significance of dark versus light-driven $\mathrm{N}$ uptake}

Light-independent $\mathrm{N}$ uptake $\left(D_{\left(\mathrm{NO}_{3} \text { and } \mathrm{NH}_{4}\right)}^{B}\right)$ is known to occur during daytime or at night when samples taken in the euphotic zone are incubated. In the short term (i.e., a few hours), $D_{\left(\mathrm{NO}_{3} \text { and } \mathrm{NH}_{4}\right)}^{B}$ cannot be assumed to support shortterm photosynthetic primary production because it can be mediated by heterotrophic bacteria (Kirchman and Wheeler, 1998; Allen et al., 2002) and the portion taken up by phytoplankton is not necessarily constitutive (i.e., not assimilated or, more precisely, not leading to amino acid synthesis; Dortch, 1982) since photosynthesis does not occur in the dark but $\mathrm{N}$ may be stored in cell vacuoles. In our study, adding $D_{\left(\mathrm{NO}_{3} \text { or } \mathrm{NH}_{4}\right)}^{B}$ to $N_{m}^{B}\left(\mathrm{NO}_{3}\right.$ or $\left.\mathrm{NH}_{4}\right)$ generally had a modest impact on the $f$-ratio, translating into potential errors of only $4-17 \%$ (9\% on average) in new production estimates. However, $D_{\left(\mathrm{NO}_{3} \text { and } \mathrm{NH}_{4}\right)}^{B}$ represented a variable and sometime high proportion of total $\mathrm{N}$ uptake and its role in nutrition and $\mathrm{N}$ cycling needs to be discussed.

Using antibiotics and $0.2 \mu \mathrm{m}$ filters, Berrouard (2011) estimated absolute bacterial uptake rates in our study area to be $0.0017 \pm 0.0019 \mu \mathrm{g} \mathrm{L}^{-1} \mathrm{~h}^{-1}$ for $\mathrm{NO}_{3}^{-}$and $0.0032 \pm 0.0061 \mu \mathrm{g} \mathrm{N} \mathrm{L}^{-1} \mathrm{~h}^{-1}$ for $\mathrm{NH}_{4}^{+}$, on average. Those numbers are close to the median absolute dark uptake $\left(D_{\left(\mathrm{NO}_{3} \text { or } \mathrm{NH}_{4}\right)}^{B} \times \mathrm{chl} a\right)$ values obtained here using GF/F filters $\left(0.0014 \mu \mathrm{g} \mathrm{N} \mathrm{L}^{-1} \mathrm{~h}^{-1}\right.$ for $\mathrm{NO}_{3}^{-} ; 0.0029 \mu \mathrm{g} \mathrm{N} \mathrm{L}^{-1} \mathrm{~h}^{-1}$ for $\mathrm{NH}_{4}^{+}$). Since over half the bacteria present in the water are retained by GF/F filters in the coastal Beaufort Sea (Simpson et al., 2012), we estimate that at least 61 and $55 \%$ of $D_{\left(\mathrm{NO}_{3}\right)}^{B}$ and $D_{\left(\mathrm{NH}_{4}\right)}^{B}$ were mediated by heterotrophs, respectively. Given this, up to 39 and $45 \%$ of $D_{\left(\mathrm{NO}_{3}\right)}^{B}$ and 
$D_{\left(\mathrm{NH}_{4}\right)}^{B}$, respectively, can be attributed to assimilation or nonconstitutive uptake by autotrophs.

Assimilatory algal $D_{\left(\mathrm{NO}_{3} \text { and } \mathrm{NH}_{4}\right)}^{B}$ requires excess $\mathrm{C}$ and energy acquired in the light prior to incubation, which is likely to be near the surface but is unlikely to occur under low light at SCM depth (where biomass is generated primarily by local growth instead of the accumulation of cells sinking from above; Martin et al., 2010). For this reason, the lack of correlation between $D_{\left(\mathrm{NH}_{4}\right)}^{B}$ and $E_{\mathrm{SCM}}$ points to a low occurrence of light-independent $\mathrm{NH}_{4}^{+}$assimilatory uptake by phytoplankton at the SCM, which is probably masked by the contribution of bacteria that use $\mathrm{NH}_{4}^{+}$preferentially. This scenario is compatible with the low ratio of $D_{\left(\mathrm{NO}_{3} \text { and } \mathrm{NH}_{4}\right)}^{B}$ to total $\mathrm{N}$ uptake at light saturation in our study compared to previous ones (Price et al., 1985; Cochlan et al., 1991; Smith and Harrison, 1991; Probyn et al., 1996). This ratio was also much lower for $\mathrm{NO}_{3}^{-}$than for reduced $\mathrm{N}$ sources, as expected from the relatively high energy cost of $\mathrm{NO}_{3}^{-}$reduction (Behrenfeld et al., 2008), which is consistent with the positive correlation between $D_{\left(\mathrm{NO}_{3}\right)}^{B}$ and $E_{\mathrm{SCM}}$. However, the algae there probably lack energy to perform both photosynthesis and the full reduction of all the $\mathrm{NO}_{3}^{-}$taken up, leading to the release of $\mathrm{NO}_{2}^{-}$(Kiefer et al., 1976; Lomas and Lipschultz, 2006) and widespread presence of a PNM near or at the SCM (see also Tremblay et al., 2008 and Martin et al., 2010). It is advantageous to use reduced $\mathrm{N}$ in this situation, which explains the negligible contribution of $\mathrm{NO}_{2}^{-}$to total $\mathrm{N}$ uptake and the positive effects of $\mathrm{NH}_{4}^{+}$enrichment on $\mathrm{NH}_{4}^{+}$ uptake (Fig. 9) and of incubation irradiance on the $f$-ratio (Fig. 7).

Since N enrichment or elevated ambient $\mathrm{N}$ concentrations did not stimulate $P_{m}^{B}$ in our study, we surmise that $D_{\left(\mathrm{NO}_{3} \text { and } \mathrm{NH}_{4}\right)}^{B}$ was mediated mostly by bacteria during incubations, with a secondary contribution of non-constitutive uptake by phytoplankton. Without $D_{\left(\mathrm{NO}_{3} \text { and } \mathrm{NH}_{4}\right)}^{B}, P^{B}: N^{B}$ ratios at $E_{\mathrm{SCM}}$ hovered near the Redfield ratio, implying that phytoplankton did not need $D_{\left(\mathrm{NO}_{3} \text { and } \mathrm{NH}_{4}\right)}^{B}$ to fulfill their N demand (Fig. 10). If anything, the autotrophic component of $D_{\left(\mathrm{NO}_{3} \text { and } \mathrm{NH}_{4}\right)}^{B}$ could result from the storage of inorganic N in the vacuoles of diatoms, which are numerically important at the SCM (Martin et al., 2010), and would explain decreasing $P_{m}^{B}: N_{m}^{B}$ ratios under $\mathrm{N}$ enrichment (Fig. 10). Whether this storage actually occurs or eventually fuels PON (particulate organic nitrogen) synthesis before the cells sink or die is unknown. For these reasons, only the light-driven component of $\mathrm{N}$ uptake will be considered for further analysis.

Based on the above considerations, our working hypothesis that $\mathrm{NO}_{3}^{-}$was the main form of $\mathrm{N}$ consumed by phytoplankton at the SCM is supported during springearly summer (the mean $f$-ratio estimated for this period $=0.74 \pm 0.26$ ). However, our hypothesis is not supported for later summer and fall, when the mean $f$-ratio declined to $0.37 \pm 0.20$ due to decreasing $\mathrm{NO}_{3}^{-}$availability and irradiance at the $\mathrm{SCM}$, which was then often lower than the
$E_{k}\left(\mathrm{NO}_{3}\right)$. While recent studies indicate that nitrification may cause the overestimation of new production in stratified waters (Raimbault et al., 1999; Yool et al., 2007), the SCM considered here were generally exposed to 24-h sunlight and located high in the euphotic zone relative to those of other oceans (Martin et al., 2010). These conditions should strongly inhibit bacterial nitrification (Horrigan et al., 1981).

\subsection{Acclimation and vertical coupling of $\mathrm{C}$ and $\mathrm{N}$ uptake}

The following discussion assumes that $\alpha$ (and thus $E_{k}$ ) estimates are reliable despite the absence of correction for possible shifts in light absorption with depth. While these shifts are known to occur, Shakshaug and Slagstad (1991) reported only small differences in $\alpha$ (ca. $\pm<0.001 \mu \mathrm{g} \mathrm{C}$ $(\mu \mathrm{g} \mathrm{chl} a)^{-1} \mathrm{~h}^{-1}\left(\mu \mathrm{mol} \text { quanta } \mathrm{m}^{-2} \mathrm{~s}^{-1}\right)^{-1}$ ) over the depth interval that separates surface and SCM samples in our study. Such a shift is similar to the statistical error attached to $\alpha$ estimates obtained with the ${ }^{13} \mathrm{C}$ method (here $\pm 11 \%$ for a mean value of 0.027 ) and one order of magnitude smaller than the observed range of $\alpha$ values $(0.027 \pm 0.014$; see also Brunelle et al., 2012)

SCM communities located in a strongly stratified environment would benefit by acclimating to low irradiance. For $\mathrm{C}$ uptake, this expectation is consistent with the contrast between the data of Platt et al. (1982), who found no vertical differences in uptake-irradiance parameters in weakly stratified waters (Baffin Bay), and our data set, where $\alpha$ was higher at the SCM than at the surface. Here, uncoupled changes in $P_{m}^{B}$ and $\alpha$ resulted in lower $E_{k}$ values for SCM communities, which maintained very high photosynthetic performance $\left(F_{v} / F_{m}\right)$. This pattern is entirely consistent with photochemical acclimation to low light instead of a physiological response to nutrient stress, senescence or the influence of taxonomic composition (i.e., $E_{k^{-}}$ independency, sensu Behrenfeld et al., 2008). The low $E_{k}$ values $\left(24 \pm 13 \mu \mathrm{mol}\right.$ quanta $\left.\mathrm{m}^{-2} \mathrm{~s}^{-1}\right)$ observed during all years and seasons at the SCM and the continuous and rapid acclimation (within 4 to 10 days) of phytoplankton to changing light conditions during the ice-open water transition in the coastal Beaufort Sea (Palmer et al., 2011) imply widespread and persistent shade acclimation. This interpretation is supported by the sharp drop (photoinhibition) in post-incubatory $F_{v} / F_{m}$ for SCM phytoplankton exposed to irradiances greater than $70 \mu \mathrm{mol}$ quanta $\mathrm{m}^{-2} \mathrm{~s}^{-1}$ (irrespective of season or region) while surface phytoplankton were able to manage higher irradiance (Fig. 11). Similar patterns were previously observed in Baffin Bay and Lancaster Sound, where samples from the surface demonstrated negligible photoinhibition relative to deeper ones under stratified conditions (Platt et al., 1982; Gallegos et al., 1983).

The photochemical acclimation observed for $\mathrm{C}$ uptake was not observed for $\mathrm{NO}_{3}^{-}$uptake, for which $N_{m}^{B}\left(\mathrm{NO}_{3}\right)$ but not $\alpha_{\left(\mathrm{NO}_{3}\right)}$ was significantly higher at the SCM than at the 
surface ( $E_{k}$-independency). Since $N_{m}^{B}\left(\mathrm{NO}_{3}\right)$ was also positively related to ambient $\mathrm{NO}_{3}^{-}$concentration (Table A1), SCM communities near the nitracline physiologically adjusted to higher $\mathrm{N}$ concentrations presumably by increasing their enzymatic capacity to reduce $\mathrm{NO}_{3}^{-}$. The general lack of increase in $N_{m}^{B}\left(\mathrm{NO}_{3}\right)$ with experimental enrichment suggests that acclimation occurred on time scales of days rather than hours. The inhibition of $\mathrm{NO}_{3}^{-}$uptake by $\mathrm{NH}_{4}^{+}$ observed in other regions (e.g., Glibert et al., 1982; Price et al., 1985; Cochlan, 1986) was not manifest in the Canadian Arctic (significant negative correlation neither between the $f$-ratio and $\mathrm{NH}_{4}^{+}$concentration as observed by Smith and Harrison (1991) nor between the $N_{m}^{B}\left(\mathrm{NO}_{3}\right)$ and in situ $\mathrm{NH}_{4}^{+}$ concentration), probably due to the fact that ambient $\mathrm{NH}_{4}^{+}$ concentrations were generally low. Inhibition is typically observed at concentration exceeding $0.5-1.0 \mu \mathrm{M}$ (McCarthy et al., 1977).

For $\mathrm{NH}_{4}^{+}$, the absence of correlation between $N_{m}^{B}\left(\mathrm{NH}_{4}\right)$ and ambient concentration was probably due to the highly dynamic nature of this $\mathrm{N}$ pool, which defeats the purpose of acclimation. However, the clear response of $N_{m}^{B}\left(\mathrm{NH}_{4}\right)$ to experimental enrichment indicates that phytoplankton can exploit sudden inputs, in accord with the minimal energy and enzymatic requirements of $\mathrm{NH}_{4}^{+}$assimilation. Despite this advantage, low ambient $\mathrm{NH}_{4}^{+}$availability forced the phytoplankton to rely strongly on $\mathrm{NO}_{3}^{-}$to fulfill their $\mathrm{N}$ demand when irradiance and $\mathrm{NO}_{3}^{-}$concentrations at the $\mathrm{SCM}$ were relatively high during spring-early summer (Fig. 7). This reliance decreased toward late summer-fall with declining irradiance and $\mathrm{NO}_{3}^{-}$availability. The synoptic manifestation of this phenomenon is well rendered by the RPI for $\mathrm{NO}_{3}^{-}$uptake and the relationship between the $f$-ratio and $\mathrm{NO}_{3}^{-}$concentration, which indicated strong "discrimination" against this $\mathrm{N}$ source at relatively low ambient concentrations (Fig. 8).

Overall, the acclimation of $\mathrm{C}$ uptake to low light and of $\mathrm{NO}_{3}^{-}$uptake to high concentrations, as well as the low cost of $\mathrm{NH}_{4}^{+}$uptake, favoured efficient $\mathrm{C}$ and $\mathrm{N}$ nutrition at the SCM. However, the different $E_{k}$ values ( $\mu$ mol quanta $\left.\mathrm{m}^{-2} \mathrm{~s}^{-1}\right)$ obtained for $\mathrm{C}(24 \pm 13), \mathrm{NO}_{3}^{-}$ $(18 \pm 12)$, and $\mathrm{NH}_{4}^{+}(7 \pm 8)$ uptake imply a measure of vertical decoupling between total, new and regenerated production. For example, using these mean $E_{k}$ values with the irradiance data of station 303 (Table 1) yields the onset of lightsaturation at depths of 34,24 and $21 \mathrm{~m}$, for $\mathrm{NH}_{4}^{+}, \mathrm{NO}_{3}^{-}$and $\mathrm{C}$ uptake, respectively. However, we did not observe differences in the vertical position of absolute maxima between total and new production (both occurred at $22 \mathrm{~m}$ : Fig. 3) because (1) the strong concentration of chl $a$ biomass at the SCM overrides the vertical separation that different $E_{k}$ values would cause (Fig. 3) and (2) $N_{m}^{B}$ for $\mathrm{NO}_{3}^{-}$uptake was twice as high as for $\mathrm{NH}_{4}^{+}$uptake at the $\mathrm{SCM}$.

Recent attempts to assess the impact of SCM on watercolumn primary production and remote-sensing estimates at the pan-Arctic scale reached different conclusions. While Arrigo et al. (2011) propose that SCM play a modest role and account for ca. $8 \%$ of pan-Arctic annual production, Popova et al. (2010) and Hill et al. (2012) assess their contribution at ca. $50 \%$. For the remote-sensing studies, the difference is presumably caused by the application of different averaging techniques to in situ profiles obtained from the ARCSS-PP database and to the different methods used to estimate watercolumn production from surface variables. The following is noteworthy:(1) the extent to which the historical field studies used for validation specifically sampled and resolved SCM layers cannot be assessed; (2) $100 \%$ and ca. $80 \%$ of the primary production data used for validation pre-date 2007 and 1998, respectively, and may not represent the present context of rapid change and increased stratification (e.g., Li et al., 2009); and (3) spatial coverage is very patchy, especially during the spring-summer transition for which few data are available. The actual contribution of SCM to primary production thus remains highly uncertain, which underscores the need to perform targeted contemporary studies on rates and function such as we have done here.

In the reconstructed profiles (Fig. 3), the depth of maximum productivity occurred at the SCM and the "classical" decrease in primary productivity with depth was not observed (Cullen, 1982; Harrison, 1990). The SCM layer mediated up to $76 \%$ of total production and up to $98 \%$ of $\mathrm{NO}_{3}^{-}$ uptake in the water column across the Canadian Archipelago during early fall. These estimates apply to one sector of the Arctic Ocean, but underscore the need to consider this structure in remote-sensing estimations of productivity in regions where strong vertical stratification prevails (e.g., the Chukchi Sea; Arrigo et al., 2011) and/or where $\mathrm{NO}_{3}^{-}$is perennially low at the surface (e.g., the Beaufort Sea).

\subsection{Environmental control of SCM productivity}

Although SCM communities were shade-adapted, several if not most (47\% for spring-early summer and $85 \%$ for late summer-fall) were exposed to $E_{\mathrm{SCM}}$ lower than the $E_{k}$ for $\mathrm{C}$ uptake (Fig. 6). Light conditions were more favourable at the remaining stations where irradiance equaled or slightly exceeded $E_{k}$ (mostly during spring-early summer), but even if $E_{\mathrm{SCM}}$ had been 2 times higher than $E_{k}$ (a condition met at only 2 out of 48 stations), $P^{B}$ would not exceed $87 \%$ of $P_{m}^{B}$ (based on Eq. 3). Primary production in the SCM layer thus operated at sub-optimal irradiance throughout most of the growth period.

Despite sub-optimal irradiance at the $\mathrm{SCM}, P_{m}^{B}$ may have been constrained by nutrient availability or temperature, which would negatively affect $P^{B}$ even when $E_{\mathrm{SCM}}$ exceeds $E_{k}$. Because the $E_{k}$ for $\mathrm{N}$ uptake was lower than for $\mathrm{C}$ uptake, we surmise that low light levels had a much lower impact on nutrition than on photosynthesis. The independency of $P_{m}^{B}$ from ambient N concentrations further suggests that total primary production was not 
nutrient-limited at the SCM and the $\mathrm{C}: \mathrm{N}$ uptake ratios at $E_{\mathrm{SCM}}\left(P^{B}: N^{B}\right)$ showed no clear sign of $\mathrm{N}$ stress under trace additions, except perhaps when ambient $\mathrm{N}$ reached the lowest values (Fig. 10). This pattern is expected in a situation where SCM communities push the nitracline downward or benefit from upward $\mathrm{N}$ fluxes in its vicinity, as long as $E_{\mathrm{SCM}}$ remains above the compensation irradiance (e.g., ca. $0.16 \pm 0.02 \mu$ mol quanta $\mathrm{m}^{-2} \mathrm{~s}^{-1}$; Tremblay et al., 2006). The much greater uptake ratios at light saturation $\left(P_{m}^{B}: N_{m}^{B}\right.$; Fig. 10) suggest the possibility of $\mathrm{N}$ stress at light levels greatly exceeding what is realistic for the SCM, consistent with the effect of $\mathrm{NH}_{4}^{+}$enrichment on $P_{m}^{B}: N_{m}^{B}$.

In polar regions, phytoplankton experience low temperatures throughout the year, but uptake-irradiance parameters do not reveal specific adaptations to this condition (Platt et al., 1982; Smith and Harrison, 1991). Given that optimum temperatures for phytoplankton growth $\left(>10^{\circ} \mathrm{C} ; \mathrm{Li}, 1985\right)$ are greater than those observed during our study, the positive correlation between $P_{m}^{B}$ and temperature during late summer-fall (Fig. 5) is expected and consistent with previous Arctic data sets (Harrison et al., 1982; Harrison and Platt, 1986; Harrison and Cota, 1991) and experimental studies (Subba Rao and Platt, 1984; Smith and Harrison, 1991). Such a correlation was not observed when excluding surface data, which was expected since the range of observed temperatures was very narrow at the SCM. The lower envelope of $P_{m}^{B}$ values at the SCM was nevertheless consistent with the temperature relationship established with surface data, especially for late summer-fall (Fig. 5). During spring and early summer, cold stations with high $P_{m}^{B}$ values at the SCM were presumably associated with fast-growing, blooming diatoms (pigment analysis indicated diatom dominance at the SCM during the ice-open water transition in the Beaufort Sea during 2008; Palmer et al., 2011). A similar temperature-independent, transient increase in $P_{m}^{B}$ was previously observed during an intense diatom bloom in northern Baffin Bay (Tremblay et al., 2006).

\subsection{Strategy and rationale for the selection of uptake-irradiance parameters}

The extensive spatial and regional coverage of our data set permits updating some of the parameters used in ecosystem models and remote-sensing algorithms for the Arctic (Table 2). Although the uptake-irradiance parameters reported here showed no obvious regional or seasonal patterns, the typical $P_{m}^{B}$ constant of $\left.2 \mu \mathrm{g} \mathrm{C}(\mu \mathrm{g} \mathrm{chl} a)^{-1} \mathrm{~h}^{-1}\right)$ based on previous studies (Harrison and Platt, 1980; Subba Rao and Platt, 1984; Harrison and Cota, 1991; Smith and Harrison, 1991; Weston et al., 2005) clearly needs to be reconsidered.

When considering spring-early summer only, $P_{m}^{B}$ can be approximated as a function of day of the year (which integrates a complex set of interaction between environmental parameters, e.g., surface irradiance, SCM depth, nutrient availability, stratification) and temperature
Table 2. Summary of parameterization proposed for different case scenarios.

\begin{tabular}{|c|c|c|}
\hline & Spring-early summer & Late summer-fall \\
\hline$P_{m}^{B}$ & \multicolumn{2}{|c|}{$0.65 \pm 0.45 \mu \mathrm{g} \mathrm{C}(\mu \mathrm{g} \operatorname{chl} a)^{-1} \mathrm{~h}^{-1}$} \\
\hline$P_{m}^{B} v s T$ & $P_{m}^{B}=8.417-0.0229 \mathrm{DY}+2.742 \mathrm{~T}$ & $P_{m}^{B}=0.178 T+0.538^{*}$ \\
\hline$E_{k \text { suface }}$ & \multicolumn{2}{|c|}{ ca. 60 umol quanta $\mathrm{m}^{-2} \mathrm{~s}^{-1 * *}$} \\
\hline$E_{k} \mathrm{SCM}$ & \multicolumn{2}{|c|}{$24 \pm 13$ umol quanta $\mathrm{m}^{-2} \mathrm{~s}^{-1}$} \\
\hline$N_{m}^{B}\left(\mathrm{NO}_{3}\right)$ & \multicolumn{2}{|c|}{$N_{m}^{B} \quad \mathrm{NO}_{2}=-0.0005 \mathrm{DY}+0.16$} \\
\hline$f$-ratio & 0.74 & 0.30 \\
\hline$f$-ratiosCM & 0.74 & 0.37 \\
\hline$f$-ratio vs. $\mathrm{NO}_{3}^{-}$ & \multicolumn{2}{|l|}{$0.1 \mathrm{NO}_{3}^{-}+0.3$} \\
\hline
\end{tabular}

* Also applicable to post-bloom estimations.

** Arrigo et al. (2011); Palmer et al. (2011)

(e.g., $\left.P_{m}^{B}=8.417-0.0229 \mathrm{DY}+2.742 T\right)$. Otherwise $P_{m}^{B}$ can be estimated as a function of temperature only (e.g., $P_{m}^{B}=0.178 T+0.538$; Fig. 5) for post-bloom situations spanning spring, summer and fall (since $P_{m}^{B}$ after the spring bloom apparently obeys the relationship obtained for late summer and fall). The difference in photosynthetic parameters observed between the upper mixed layer and the SCM suggests that algorithms should consider acclimation of the phytoplankton to the vertical light gradient in strongly stratified Arctic waters (e.g., implement models with at least 2 sets of parameters and ideally several that cover the vertical extent of the SCM layer).

While our data set contains few early spring data, a companion study performed in 2008 during the ice-open water transition by Palmer et al. (2011) found mean $P_{m}^{B}$ values of 1.25 and 0.82 in Franklin Bay and Darnley Bay (Beaufort Sea), respectively, similar to those reported here for spring to late fall, i.e., $P_{m}^{B}=0.65 \pm 0.45$. At the very beginning of the season, the phytoplankton seem to show a continuous and rapid acclimation (within 4 to 10 days) to changing conditions at the time of the SCM development (Palmer et al., 2011). Given this fact, the $E_{k}$ values used after that rapid early spring acclimation by algorithms below the upper mixed layer should be lower (e.g., $E_{k}=24 \pm 13 \mu \mathrm{mol}$ quanta $\left.\mathrm{m}^{-2} \mathrm{~s}^{-1}\right)$ than those prescribed for surface waters (e.g., $E_{k}$ of ca. $60 \mu$ mol quanta $\mathrm{m}^{-2} \mathrm{~s}^{-1}$; Arrigo et al., 2011; Palmer et al., 2011).

By contrast with $\mathrm{C}$ uptake, the $f$-ratio showed a relatively weak dependence on irradiance during spring-early summer. A vertically constant value of 0.74 could thus be assumed for this period. The situation was different in late summer-fall, where the $f$-ratio was relatively low even at light saturation. Considering that the SCM act as a "nutrient trap", limiting upward $\mathrm{NO}_{3}^{-}$diffusion to the surface, we would advocate using a maximum $f$-ratio of 0.3 in the upper mixed layer (derived from the relationship observed at SCM where $f$-ratio $=0.1 \mathrm{NO}_{3}^{-}+0.3$; see also Harrison, 1990). In the SCM layer, a $f$-ratio of 0.37 could be used to convert remote-sensing estimations of total $P$ into new production. In models using $\mathrm{N}$ as a currency (Fasham et al., 1990; Kuhn and Radach, 1997), a more dynamic parameterization 
Table A1. Significant correlations between water-column variables and uptake-irradiance parameters for the data set where SCM communities were incubated with trace $(T)$ or enriched $(E) \mathrm{N}$ additions.

\begin{tabular}{|c|c|c|c|c|c|c|c|c|c|c|c|c|}
\hline & \multicolumn{12}{|c|}{ Carbon } \\
\hline & \multicolumn{4}{|c|}{$P_{m}^{B}$} & \multicolumn{4}{|c|}{$E_{k}$} & \multicolumn{4}{|c|}{$\alpha$} \\
\hline & $\mathrm{NH}_{4 T}^{+}$ & $\mathrm{NO}_{3 T}^{-}$ & $\mathrm{NH}_{4 E}^{+}$ & $\mathrm{NO}_{3 E}^{-}$ & $\mathrm{NH}_{4 T}^{+}$ & $\mathrm{NO}_{3 T}^{-}$ & $\mathrm{NH}_{4 E}^{+}$ & $\mathrm{NO}_{3 E}^{-}$ & $\mathrm{NH}_{4 T}^{+}$ & $\mathrm{NO}_{3 T}^{-}$ & $\mathrm{NH}_{4 E}^{+}$ & $\mathrm{NO}_{3 E}^{-}$ \\
\hline Temperature $\left({ }^{\circ} \mathrm{C}\right)$ & $0.85^{* * *}$ & $0.73^{* * *}$ & - & $0.86^{* * *}$ & $0.88^{* * *}$ & $0.79^{* * *}$ & - & $0.88^{* * *}$ & - & - & - & - \\
\hline Day of the year & - & - & $-0.53^{* *}$ & - & - & - & - & - & - & - & - & - \\
\hline$[\operatorname{chl} a]\left(\mathrm{g} \mathrm{L}^{-1}\right)$ & - & - & $0.51^{* *}$ & - & - & - & $0.43^{*}$ & - & - & - & - & - \\
\hline$\left[\mathrm{NO}_{3}^{-}\right](\mu \mathrm{M})$ & - & - & - & - & - & - & - & - & - & - & - & - \\
\hline$\left[\mathrm{NO}_{2}^{-}\right](\mu \mathrm{M})$ & - & - & - & - & - & - & - & - & $-0.39^{*}$ & - & - & - \\
\hline$\left[\mathrm{NH}_{4}^{+}\right](\mu \mathrm{M})$ & - & - & - & - & - & - & - & - & $0.46^{*}$ & - & - & - \\
\hline Total $[\mathrm{N}](\mu \mathrm{M})$ & - & - & - & - & - & - & - & - & - & - & - & - \\
\hline \multirow[t]{4}{*}{$E_{\mathrm{SCM}}$} & - & - & $0.49^{*}$ & - & - & - & $0.48^{*}$ & - & - & - & - & - \\
\hline & \multicolumn{12}{|c|}{ Nitrogen } \\
\hline & \multicolumn{4}{|c|}{$N_{m}^{B}$} & \multicolumn{4}{|c|}{$E_{k}$} & \multicolumn{4}{|c|}{$\alpha$} \\
\hline & $\mathrm{NH}_{4 T}^{+}$ & $\mathrm{NO}_{3 T}^{-}$ & $\mathrm{NH}_{4 E}^{+}$ & $\mathrm{NO}_{3 E}^{-}$ & $\mathrm{NH}_{4 T}^{+}$ & $\mathrm{NO}_{3 T}^{-}$ & $\mathrm{NH}_{4 E}^{+}$ & $\mathrm{NO}_{3 E}^{-}$ & $\mathrm{NH}_{4 T}^{+}$ & $\mathrm{NO}_{3 T}^{-}$ & $\mathrm{NH}_{4 E}^{+}$ & $\mathrm{NO}_{3 E}^{-}$ \\
\hline Temperature $\left({ }^{\circ} \mathrm{C}\right)$ & - & - & - & - & - & - & - & - & - & - & - & - \\
\hline Day of the year & - & $-0.36^{*}$ & $-0.50^{* *}$ & $-0.60^{* * *}$ & - & - & - & - & - & - & $-0.44^{*}$ & $-0.61^{* * *}$ \\
\hline$[\operatorname{chl} a](\mu \mathrm{g} \mathrm{L}-1)$ & - & - & $0.53^{* *}$ & $0.58^{* * *}$ & - & - & - & - & - & $0.36^{*}$ & $0.37^{*}$ & $0.54^{* *}$ \\
\hline$\left[\mathrm{NO}_{3}^{-}\right](\mu \mathrm{M})$ & - & $0.52^{* *}$ & - & - & - & - & - & - & - & $0.35^{*}$ & - & $0.35^{*}$ \\
\hline$\left[\mathrm{NO}_{2}^{-}\right](\mu \mathrm{M})$ & - & $0.53^{* *}$ & - & - & - & - & - & - & - & - & - & - \\
\hline$\left[\mathrm{NH}_{4}^{+}\right](\mu \mathrm{M})$ & - & - & - & - & - & - & - & - & - & - & - & - \\
\hline Total $[\mathrm{N}](\mu \mathrm{M})$ & - & $0.52^{* *}$ & - & - & - & - & - & - & - & $0.36^{*}$ & - & - \\
\hline$E_{\mathrm{SCM}}$ & - & - & $0.67^{* * *}$ & $0.62^{* * *}$ & - & - & $0.44^{*}$ & - & - & - & - & - \\
\hline
\end{tabular}

${ }^{*}: p<0.05 ;^{* *}: p<0.01 ;{ }^{* * *}: p<0.001$

of $N_{m}^{B}$ according to the day of year could be achieved (e.g., $\left.N_{m}^{B}\left(\mathrm{NO}_{3}\right)=-0.0005 \mathrm{DY}+0.16\right)$.

\section{Conclusions}

Data collected over the full extent of the growth season in the Canadian Arctic revealed that primary production at the SCM is generally co-limited by light and temperature. Nevertheless, SCM communities (1) show high photosynthetic competence, (2) are well acclimated to low light conditions and (3) can be photoinhibited by irradiance levels typical of those prevailing in the upper mixed layer. These communities consume predominately $\mathrm{NO}_{3}^{-}$during spring-early summer, but their reliance on $\mathrm{NO}_{3}^{-}$decreases seasonally as the algae eventually discriminate against this $\mathrm{N}$ source and use mostly $\mathrm{NH}_{4}^{+}$. The low concentrations of $\mathrm{NH}_{4}^{+}$in the water column could explain the association observed between the SCM and the nitracline, where the phytoplankton can meet their $\mathrm{N}$ demand.

The sheer size of the Canadian Arctic, combined with the unique and dynamic nature of phytoplankton communities at widespread SCM, demonstrates the need to adapt ecosystem models and remote-sensing algorithms to the strong temporal and vertical gradients of temperature, irradiance and nutrient concentrations. This is especially relevant in strongly stratified Arctic regions (e.g., Canadian Arctic, Chukchi Sea), which presumably host the most understudied yet strongly perturbed marine ecosystems of the global ocean. A more effective parameterization could also consider the vertical and seasonal dynamics of $\mathrm{N}$ uptake parameters for different $\mathrm{N}$ substrates and the change observed in the ratio of new to total production throughout the growth season.

Tremblay and Gagnon (2009) proposed that the major differences in productivity and trophic status at the pan-Arctic scale are controlled by nutrient supply to the surface, which is typically greater in polynyas or peripheral areas with a short ice-covered season. Within a given region, productivity can increase with the duration of the ice-free season (Pabi et al., 2008; Arrigo et al., 2011), but the relative role of nutrient re-supply versus greater exposure to irradiance on this trend is unknown. Here, we showed how the latter may act in synergy with rising temperature and lead to greater productivity by SCM layers, either through more complete $\mathrm{NO}_{3}^{-}$usage or by deepening of the nitracline. In this regard, the physical processes that affect the vertical position of the nitracline (e.g., McLaughlin and Carmack, 2010) are also expected to influence new production at the SCM. 


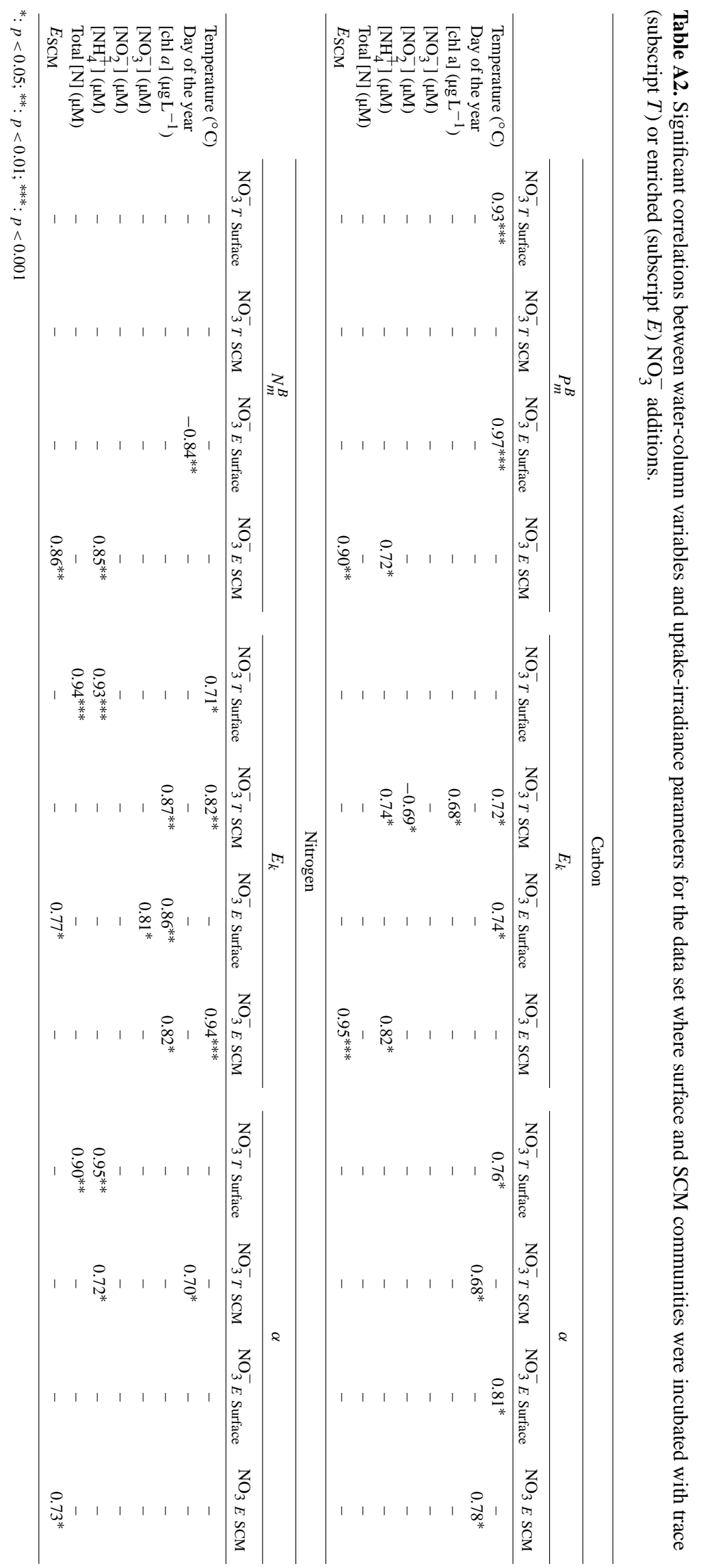


Table B1. Summary of uptake-irradiance parameters for $\mathrm{N}$ uptake (trace ${ }^{15} \mathrm{~N}$ additions) at the SCM.

\begin{tabular}{|c|c|c|c|c|c|}
\hline & \multicolumn{5}{|c|}{$\mathrm{NO}_{3}^{-}$} \\
\hline & $\begin{array}{c}N_{m}^{B} \\
\left.\mu \mathrm{g} \mathrm{N}(\mu \mathrm{g} \operatorname{chl} a)^{-1} \mathrm{~h}^{-1}\right)\end{array}$ & 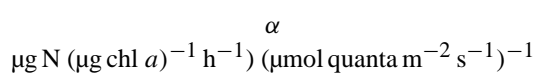 & $\begin{array}{c}E_{k} \\
\mu \text { mol quanta } \mathrm{m}^{-2} \mathrm{~s}^{-1}\end{array}$ & $\begin{array}{c}D^{B} \\
\left.\mu \mathrm{g} \mathrm{N}(\mu \mathrm{g} \operatorname{chl} a)^{-1} \mathrm{~h}^{-1}\right)\end{array}$ & $\begin{array}{l}\text { Relative } D^{B} \\
\quad \%\end{array}$ \\
\hline Mean $( \pm$ SD) & $0.042 \pm 0.043$ & $0.004 \pm 0.003$ & $18 \pm 12$ & $0.010 \pm 0.030$ & $14 \pm 17$ \\
\hline Minimum & 0.001 & 0 & 1 & 0 & 0 \\
\hline \multirow[t]{3}{*}{ Maximum } & 0.210 & 0.040 & 57 & 0.210 & 64 \\
\hline & \multicolumn{5}{|c|}{$\mathrm{NH}_{4}^{-}$} \\
\hline & $\begin{array}{c}N_{m}^{B} \\
\left.\mu \mathrm{g} \mathrm{N}(\mu \mathrm{g} \operatorname{chl} a)^{-1} \mathrm{~h}^{-1}\right)\end{array}$ & 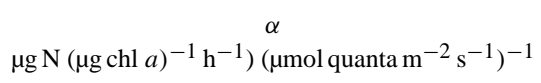 & $\begin{array}{c}E_{k} \\
\mu \text { mol quanta } \mathrm{m}^{-2} \mathrm{~s}^{-1}\end{array}$ & $\begin{array}{c}D^{B} \\
\left.\mu \mathrm{g} \mathrm{N}(\mu \mathrm{g} \operatorname{chl} a)^{-1} \mathrm{~h}^{-1}\right)\end{array}$ & $\begin{array}{c}\text { Relative } D^{B} \\
\%\end{array}$ \\
\hline Mean $( \pm D)$ & $0.016 \pm 0.017$ & $0.005 \pm 0.008$ & $7 \pm 8$ & $0.008 \pm 0.009$ & $26 \pm 24$ \\
\hline Minimum & 0 & 0 & 1 & 0 & 0 \\
\hline Maximum & 0.070 & 0.039 & 43 & 0.030 & 80 \\
\hline
\end{tabular}

Acknowledgements. The authors would like to thank J. Gagnon, the crew and the scientists of the CCGS Amundsen for their valuable support in the field, T. Papakyriakou for in situ irradiance data and CTD-rosette operators, especially Y. Gratton, M.-E. Rail, V. Lago and P. Guillot, for collecting and processing CTD data. This study was supported by Canadian Network Centres of Excellence (NCE) ArcticNet, and the Natural Sciences and Engineering Research Council of Canada (NSERC). Partial operating funds for the CCGS Amundsen were provided by the International Joint Ventures Fund of the Canada Foundation for Innovation and the Fonds québécois de la recherche sur la nature et les technologies (FQRNT). This study is a scientific contribution to ArcticNet, Québec-Océan, IPY-Circumpolar Flaw Lead System Study and the Canada Research Chair on the response of Marine Ecosystems to Climate Change programs.

Edited by: K. Suzuki

\section{References}

Allen, A. E., Howart-Jones, M. H., Booth, M. G., Frisher, M. E., Verity, P. G., Bronk, D. A., and Sanderson, M. P.: Importance of heterotrophic bacterial assimilation of ammonium and nitrate in the Barents Sea during summer, J. Mar. Syst., 38, 93-108, 2012.

Ardyna, M., Gosselin, M., Michel, C., Poulin, M., and Tremblay, J. E.: Environmental forcing of phytoplankton community structure and function in the Canadian High Arctic: contrasting oligotrophic and eutrophic regions, Mar. Ecol.-Prog. Ser., 442, 3753, 2011.

Arrigo, K. R., Matrai, P. A., and Dijken, G.: Primary productivity in the Arctic Ocean: Impacts of complex optical properties and subsurface chlorophyll maxima on large-scale estimates, J. Geophys. Res., 116, C11022, doi:10.1029/2011JC007273, 2011.

Babin, M., Morel, A., and Gagnon, R.: An incubator designed for extensive and sensitive measurements of phytoplankton photosynthetic parameters, Limnol. Oceanogr., 39, 694-702, 1994.

Behrenfeld, M. J., Halsey, K. H., and Milligan, A. J.: Evolved physiological responses of phytoplankton to their integrated growth environment, Philos. T. Roy. Soc. B, 363, 2687-2703, 2008.
Berrouard, M.: Contribution des bactéries hétérotrophes au cycle marin de l'azote dans l'océan Arctique canadien, in: Biology, Quebec City, Laval University, Master, p. 53, 2011.

Blais, M., Tremblay, J. E., Lovejoy, C., Jungblunt, A. D., Gagnon, J., Martin, J., and Thaler, M.: Nitrogen fixation and identification of potential diazotrophs in the Canadian Arctic, Global Biogeochem. Cy., 26, GB3022, doi:10.1029/2011GB004096, 2012.

Brugel, S., Nozais, C., Poulin, M., Tremblay, J. E., Miller, L. A., Simpson, K. G., Gratton, Y., and Demers, S.: Phytoplankton biomass and production in the southeastern Beaufort Sea in autumn 2002 and 2003, Mar. Ecol., Progress Series, 377, 63-77, 2009.

Brunelle, C. B., Larouche, P., and Gosselin, M.: Variability of phytoplankton light absorption in Canadian Arctic seas, J. Geophys. Res., 117, C00G17, doi:10.1029/2011JC007345, 2012.

Carmack, E. C., Macdonald, R. W., and Jasper, S.: Phytoplankton productivity on the Canadian Shelf of the Beaufort Sea, Mar. Ecol.-Prog. Ser., 277, 37-50, 2004.

Cochlan, W. P.: Seasonal study of uptake and regeneration on nitrogen on the Scotian Shelf, Cont. Shelf Res., 5, 555-577, 1986.

Cochlan, W. P., Harrison, P. J., and Denman, K. L.: Diel Periodicity of Nitrogen Uptake by Marine Phytoplankton in Nitrate-Rich Environments, Limnol. Oceanogr., 36, 1689-1700, 1991.

Collos, Y.: Calculations of N-15 Uptake Rates by Phytoplankton Assimilating One or Several Nitrogen-Sources, Appl. Radiat. Isotop., 38, 275-282, 1987.

Cota, G. F., Pomeroy, L. R., Harrison, W. G., Jones, E. P., Peters, F., Sheldon, W. M., and Weingartner, T. R.: Nutrients, primary production and microbial heterotrophy in the southeastern Chukchi Sea: Arctic summer nutrient depletion and heterotrophy, Mar. Ecol.-Prog. Ser., 135, 247-258, 1996.

Cullen, J. J.: The deep chlorophyll maximum: comparing vertical profiles of chlorophyll $a$, Can. J. Fish. Aquat. Sci., 39, 791-803, 1982.

Dortch, Q.: Effect of growth conditions on accumulation of internal nitrate, ammonium, amino acids, and protein in three marine diatoms, J. Exp. Mar. Biol. Ecol., 61, 243-264, 1982.

Fasham, M. J. R., Ducklow, H. W., and McKelvie, S. M.: A nitrogen-based model of plankton dynamics in the oceanic mixed layer, J. Mar. Res., 48, 591-639, 1990. 
Fouilland, E., Gosselin, M., Rivkin, R. B., Vasseur, C., and Mostajir, B.: Nitrogen uptake by heterotrophic bacteria and phytoplankton in Arctic surface waters, J. Plankton Res., 29, 369-379, 2007.

Frenette, J.-J., Demers, S., Legendre, L., and Dodson, J.: Lack of Agreement Among Models for Estimating the Photosynthetic Parameters, Limnol. Oceanogr., 38, 679-687, 1993.

Gallegos, C. L., Platt, T., Harrison, W. G., and Irving, B.: Photosynthetic Parameters of Arctic Marine Phytoplankton: Vertical Variations and Time Scales of Adaptation, Limnol. Oceanogr., 28, 698-708, 1983.

Glibert, P. M., Biggs, D. C., and McCarthy, J. J.: Utilization of ammonium and nitrate during austral summer in the Scotia Sea, Deep-Sea Res., 29, 837-850, 1982.

Goeyens, L., Kindermans, N., Abu Yusulf, M., and Elskens, M.: A Room Temperature Procedure for the Manual Determination of Urea in Seawater, Estuar. Coast. Shelf Sci., 47, 415-418, 1998.

Gosselin, M., Legendre, L., Therriault, J. C., Demers, S., and Rochet, M.: Physical control of the horizontal patchiness of sea-ice microalgae, Mar. Ecol.-Prog. Ser., 29, 289-298, 1986.

Grasshoff, K., Kremling, K., and Ehrhardt, M. (Eds.): Methods of seawater analysis, Wiley-VCH, New York, 1999.

Harrison, P. J., Conway, H. L., Holmes, R. W., and Davis, C. O.: Marine Diatoms Grown in Chemostats under Silicate and Ammonium Limitation, III. Cellular Chemical Composition and Morphology of Chaetoceros debilis, Skeletonema costatum, and Thalassiosira gravida, Mar. Biol., 43, 19-31, 1977.

Harrison, W. G.: Nitrogen utilisation in chlorophyll and primary productivity maximum layers: an analysis based on the f-ratio, Mar. Ecol.-Prog. Ser., 60, 85-90, 1990.

Harrison, W. G. and Cota, G. F.: Primary production in polar waters: relation to nutrient availability, Pro Mare Symposium on Polar Marine Ecology, Polar Research, Trondheim, 1991.

Harrison, W. G. and Platt, T.: Variations in assimilation number of coastal marine phytoplankton: Effects of environment covariates, J. Plankton Res., 2, 249-260, 1980.

Harrison, W. G. and Platt, T.: Photosynthesis-Irradiance Relationships in Polar and Temperate Phytoplakton Populations, Polar Biol., 5, 153-164, 1986.

Harrison, W. G., Platt, T., and Irwin, B.: Primary Production and Nutrient Assimilation by Natural Phytoplankton Populations of the Eastern Canadian Arctic, Can. J. Fish. Aquat. Sci., 39, 335345, 1982.

Hill, V. and Cota, G. F.: Spatial patterns of prmar production on the shelf, slope and basin of the Western Arctic in 2002, Deep-Sea Res. Pt. II, 52, 3344-3354, 2005.

Hill, V., Matrai, P. A., Olson, E., Suttles, S., Steele, M., Codispoti, L. A., and Zimmerman, R. C.: Synthesis of integrated primary production in the Arctic Ocean: II. In situ and remotely sensed estimated, Prog. Oceanogr., in press, 2012.

Hirche, H.-J., Baumann, M. E. M., Kattner, G., and Gradinger, R.: Plankton distribution and the impact of copepod grazing on primary production in Fram Strait, Greenland Sea, J. Mar. Syst., 2, 477-494, 1991.

Holmes, R. M., Aminot, A., Kerouel, R., Hooker, B. A., and Peterson, J. B.: A simple and precise method for measuring ammonium in marine and freshwater ecosystems, Can. J. Fish. Aquat. Sci., 56, 1801-1808, 1999.
Horrigan, S. G., CArlucci, A. F., and Williams, R. G.: Light inhibition of nitrification in sea-surface films, J. Mar. Res., 39, 557$565,1981$.

Kiefer, D. A., Olson, R. J., and Holm-Hansen, O.: Another look at the nitrite and chlorophyll maxima in the central North Pacific, Deep-Sea Res., 23, 1199-1208, 1976.

Kirchman, D. L. and Wheeler, P. A.: Uptake of ammonium and nitrate by heterotrophic bacteria and phytoplankton in the subArctic Pacific, Deep-Sea Res. Pt. I, 45, 347-365, 1998.

Kristiansen, S. and Farbrot, T.: Nitrogen uptake rates in phytoplankton and ice algae in the Barents Sea, Proceedings of the Pro Mare Symposium on Polar Marine Ecology, 12-16 May 1990, Polar Research, Trondheim, 1991.

Kristiansen, S., Farbrot, T., and Wheeler, P. A.: Nitrogen cycling in the Barents Sea - Seasonal dynamics of new and regenerated production in the marginal ice zone, Limnol. Oceanogr., 39, 16301642, 1994.

Kristiansen, S. and Lund, B. A.: Nitrogen cycling in the Barent Sea - I. Uptake of nitrogen in the water column, Deep-Sea Res., 36, 255-268, 1989.

Kuhn, W. and Radach, G.: A one-dimensional physical-biological model study of the pelagic nitrogen cycling during the spring bloom in the northern North Sea (FLEX '76), J. Mar. Res., 55, 687-734, 1997.

Lewis, M. R. and Smith, J. C.: A small volume, short-incubationtime method for measurement of photosynthesis aas a function of incident irradiance, Mar. Ecol.-Prog. Ser., 13, 99-102, 1983.

Li, W.: Photosynthetic response to temperature on marine phytoplankton along a latitudinal gradient $\left(16^{\circ} \mathrm{N}\right.$ to $\left.74^{\circ} \mathrm{N}\right)$, Deep-Sea Res., 32, 1381-1391, 1985.

Li, W., McLaughlin, F. A., Lovejoy, C., and Carmack, E. C.: Smallest Algae Thrive As the Arctic Ocean Freshens, Science, 326, p. 539, 2009.

Lomas, M. W. and Lipschultz, F.: Forming the primary nitrite maximum: nitrifiers or phytoplankton?, Limnol. Oceanogr., 51, 24532467, 2006.

Martin, J., Tremblay, J. E., Gagnon, J., Tremblay, G., Lapoussiere, A., Jose, C., Poulin, M., Gosselin, M., Gratton, Y., and Michel, C.: Prevalence, structure and properties of subsurface chlorophyll maxima in Canadian Arctic waters, Mar. Ecol.-Prog. Ser., 412, 69-84, 2010.

McCarthy, J. J., Taylor, W. R., and Taft, J. L.: Nitrogenous Nutrition of the Plankton in the Chesapeake Bay, 1. Nutrient Availability and Phytoplankton Preferences, Limnol. Oceanogr., 22, 996-1011, 1977.

McLaughlin, F. A. and Carmack, E. C.: Deepening of the nutricline and chlorophyll maximum in the Canada Basin interior, 2003-2009, Geophys. Res. Lett., 37, L24602, doi:10.1029/2010GL045459, 2010.

Mei, Z.-P., Legendre, L., Gratton, Y., Tremblay, J. E., LeBlanc, B., Mundy, C., Klein, B., Gosselin, M., Larouche, P., Papakyriakou, T. N., Lovejoy, C., and von Quillfeldt, C. G.: Physical control of spring-summer phytoplankton dynamics in the North Water, April-July 1998, Deep-Sea Res. Pt. II, 49, 4959-4982, 2002.

Mulvenna, P. F. and Savidge, G.: A Modified Manual Method for the Determination of Urea in Seawater using Diacetylmonoxime Reagent, Estuar. Coast. Shelf Sci., 34, 429-438, 1992. 
Pabi, S., Dijken, G., and Arrigo, K. R.: Primary production in the Arctic Ocean, 1998-2006, J. Geophys. Res., 113, C08005, doi:10.1029/2007JC004578, 2008.

Palmer, M., Arrigo, K., Mundy, C., Ehn, J., Gosselin, M., Barber, D., Martin, J., Alou, E., Roy, S., and Tremblay, J.-É.: Spatial and temporal variation of photosynthetic parameters in natural phytoplankton assemblages in the Beaufort Sea, Canadian Arctic, Polar Biol., 34, 1915-1928, 2011.

Parsons, T. R., Maita, Y., and Lalli, C. M.: A manual of chemical and biological methods for seawater analysis, Pergamon Press, Toronto, 1984.

Platt, T., Gallegos, C. L., and Harrison, W. G.: Photoinhibition of photosynthesis in natural assemblages of marine phytoplankton, J. Mar. Res., 38, 687-701, 1980.

Platt, T., Harrison, W. G., Irwin, B., Horne, E. P., and Gallegos, C. L.: Photosynthesis and photoadaptation of marine phytoplankton in the Arctic, Deep-Sea Res., 29, 1159-1170, 1982.

Popova, E. E., Yool, A., Coward, A. C., Aksenov, Y. K., Alderson, S. G., de Cuevas, B. A., and Anderson, T. R.: Control of primary production in the Arctic by nutrients and light: insights from a high resolution ocean general circulation model, Biogeosciences, 7, 3569-3591, doi:10.5194/bg-7-3569-2010, 2010.

Price, N. M., Cochlan, W. P., and Harrison, P. J.: Time course of uptake of inorganic and organic nitrogen by phytoplankton in the Strait of Georgoa: comparison of frontal and stratified communities, Mar. Ecol.-Prog. Ser., 27, 39-53, 1985.

Priscu, J. C.: Photon dependence of inorganic nitrogen transport by phytoplankton in perennially ice-covered antarctic lakes, Hydrobiologia, 172, 173-182, 1989.

Probyn, T. A., Waldron, H. N., Searson, S., and Owens, N. J. P.: Diel vaiability in nitrogenous nutrient uptake at photic ans sub-photic depths, J. Plankton Res., 118, 2063-2079, 1996.

Raimbault, P., Slawyk, G., Boudjellal, B., Coatanoan, C., Conan, P., Coste, B., Garcia, N., Moutin, T., and Pujo-Pay, M.: Carbon and nitrogen uptake and export in the equatorial Pacific at $150^{\circ} \mathrm{W}$ : evidence of an efficient regenerated production cycle, J. Geophys. Res., 104, 3341-3356, 1999.

Sakshaug, E.: Primary and secondary production in the Arctic seas, in: The organic carbon cycle in the Arctic Ocean, edited by: Stein, R. and Macdonald, R. W., Springer-Verlag, Berlin, 57-81, 2004.

Sakshaug, E. and Slagstad, D.: Light and productivity of phytoplankton in polar marine ecosystems: a physiological view, Proceedings of the Pro Mare Symposium on Polar Marine Ecology, 12-16 May 1990, Polar Research, Trondheim, 1991.
Simpson, K. G., Tremblay, J. E., Brugel, S., and Price, N. M.: Nutrient dynamics on the Mackenzie Shelf and in the Cape Bathurst Polynya and Amundsen Gulf: 2. Stable isotope tracer estimates of new and regenerated production, in preparation, 2012.

Smith, W. O. and Harrison, W. G.: New production in polar regions: the role of environmental controls, Deep-Sea Res., 38, 14631479, 1991.

Subba Rao, D. V. and Platt, T.: Primary Production of Arctic Waters, Polar Biol., 3, 191-201, 1984.

Taylor, A. H., Harris, J. R. W., and Aiken, J.: The interaction of physical and biological processes in a model of the vertical distribution of phytoplankton under stratification, Elsevier Oceanograghy Serie 42, Elsevier, 313-330, 1986.

Tremblay, J. É. and Gagnon, J.: The effect of irradiance and nutrinet supply on the productivity of Arctic waters: a perspective on climate change, in: Influence of Climate Change on the Changing Arctic and Sub-Arctic Conditions, edited by: Nihoul, J. C. J. and Kostianoy, A. G., Springer Verlag, Dordrecht, The Netherlands, 73-94, 2009.

Tremblay, J. É., Gratton, Y., Carmack, E. C., Payne, C. D., and Price, N. M.: Impact of the large-scale Arctic circulation and the North Water Polynya on nutrient inventories in Baffin Bay, J. Geophys. Res., 107, 3112, doi:10.1029/2000JC000595, 2002.

Tremblay, J. É., Michel, C., Hobson, K. A., Gosselin, M., and Price, N. M.: Bloom dynamics in early opening waters of the Arctic Ocean, Limnol. Oceanogr., 51, 900-912, 2006.

Tremblay, J. É., Simpson, K., Martin, J., Miller, L., Gratton, Y., Barber, D., and Price, N. M.: Vertical stability and the annual dynamics of nutrients and chlorophyll fluorescence in the coastal, southeast Beaufort Sea, J. Geophys. Res., 113, C07S09, doi:10.1029/2007JC004547, 2008.

Webb, W. L., Newton, M., and Starr, D.: Carbon dioxide exchange of Alnus rubra: A mathematical model, Oecologia, 17, 281-291, 1974.

Weston, K., Fernand, L., Mills, D. K., Delahunty, R., and Brown, J.: Primary production in the deep chlorophyll maximum of the central North Sea, J. Plankton Res., 27, 909-922, 2005.

Yool, A., Martin, A. P., Fernández, C., and Clark, D. R.: The significance of nitrification for oceanic new production, Nature, 447, 999-1002, doi:10.1038/nature05885, 2007. 